\title{
Influence of the Ingestion of the Sea-weeds on the Thyroidal Uptake of $\mathrm{I}^{131}$
}

\author{
By \\ Shiro IINO, Kunio MATSUDA, Jun ISHII, \\ Minoru IRIE \& Kazuo SHIZUME
}

Department of Internal Medicine, University of Tokyo School of Medicine

(Director : Prof. Shigeo Okinaka)

In Japan sea-weeds are commonly taken as food. As they are relatively rich in iodine content, it is conceivable that the thyroidal uptake of radioactive iodine is inhibited by ingesting them. But there have been no precise reports concerning the effect of the ingestion of the sea-weeds on the thyroidal uptake of radioactive iodine.

In this report the effect of sea-weeds on the uptake of $\mathrm{I}^{131}$ by the thyroid gland was studied and the following results were obtained:

1. In ten normal persons tangle (Laminaria japonica), which is rich in iodine $(0.31 \%$ of dry weight), was given between 7 to 16 gms. daily for one to fourteen days. In all cases remarkable inhibition of I131-uptake was observed. Uptake values returned to the previous level about two weeks after discontinuing the ingestion.

2. In seven persons laver (Enteromorpha compressa), which contains relatively small amount of iodine (less than $0.03 \%$ of dry weight), was given between 1.2 to $3.2 \mathrm{gms}$. daily for two to fourteen days, but in no cases the inhibition of $\mathrm{I}^{131}$-uptake was observed by these doses.

3. In four patients with Graves' disease $10 \mathrm{gms}$. of tangle was given for four to six days. In all cases $\mathrm{I}^{131}$-uptake was markedly inhibited, but the uptake values returned to the previous level about two weeks after cessation of the ingestion.

4. In five patients very low uptake values were observed due to the long term ingestion of tangle ranging from three months to ten years. About two weeks after discontinuing the ingestion the uptake values returned nearly to the previous level.

From these results it was stressed to pay special attention for the previous ingestion of sea-weeds in the $\mathrm{I}^{131}$-uptake study in Japan.

\section{Study on the Mutual Transit of Sexual Hormones in Parabiotic Rats}

\author{
Influence of Hormones in the Pregnancy to Mammary
}

Gland of Non-Pregnant Rats

By

\section{Tokio NAGATA}

Department of Obstetrics \& Gynecology, Nippon Medical College (Director: Prof. Dr. S. Mitani)

(1) The following results were obtained by making a parabiotic experiment on pregnant rats and 
searching changes appeared in mammary gland of partner sides (non-pregnant rats) day by day histologically.

(a) It is recognized the hormone of pregnant rats is transited to the partner sides and give changes to mammary gland of same.

(b) It is conceivable that excessive hormone is secreted in the body of pregnant rats at the parabiotic experiment.

(c) The changes appeared in mammary gland of the partner sides showed multiplication and status of secretion different from usual pregnant changes.

(d) No difference is recognized in the growth develompent of mammary gland of the partner sides between mature female and castrated female.

(2) In prior to the experiment, as the basic study of mammary gland of the rats searches were made day by day and histologically as to mammary gland of each physiological period (pregnancy, delivery, lactation, ablactation), and made endocrinological consideration as to its observation. 


\title{
Parabiose 白鼠の相互 Hormon 移行に関する研究
}

\author{
（妊張時 Hormonの非妊側白鼠乳腺に及ぼす影響）
}

日本医科大学第二医院産婦人科教空（主任三谷茂教授）

永田 登喜 雄

緒

言

妊娠した生体内に循環する Hormon は Progesterone を主として各種 Hormon が集合関連して妊娠とい う女性特有の生理を営んでいるものであるととは云うまでもない，その Hormon 虻主に胎盤に由来すると 云われているが，生体内の各内分泌臟器き娃娠により非妊㬨と织別な特異な働き老行い複雑な相互関係によ り姃娠を完全に維持持続させる働きをする ${ }^{14)}$.

私岕この妊娠㭙の実際に循環結等される生体内の Hormon を研究すべく, 生物学的㭘索として Parabiose 法（以下 Parabiose を $\mathrm{P}$ 之略記する）を用いて実験的研究を行つたＰ法に於ける Hormon の移行に関す る研究は, 昭和26年以来当教室に於いて, 各種の Hormon 亿ついて研究発表して来た ${ }^{177,18), 239}$ 私もこの実 験法により，実際に生体内に循環する Hormon を，之のまま利用し得る特徵を生加すべく本穾験を行つた。 即ち，妊娠した鼠を用いて，非妊白鼠を相手としたP を行い，相手側て移行する Hormon の標的臟器と して特に乳腺を撰んだ。そして考察を組織学的检索によつて行い，その結果について内分泌学的考察を加え て莭か知見を得たので報告する。

尚, 白鼠乳腺の基礎的研究として各生理期に於ける乳腚の態度, 即ち非娃期, 妊娠期, 产裖期, 離乳期等 に於ける乳腺の变化を組織学的に遂日的に検索した，而して各時期に於ける発育乃至機能の関係をも究明し た.

\section{第 1 編 組織学的考察による白鼠乳腺の基礎的研究}

\section{第 1 章 実 験 要 旨}

乳腺统思春期に至り第 2 次性徴として発育が增し, 姃娠により更に顕著な增殖が起き, 分娩後産褯期に至 つて泌乳現象が生ずるが，離乳により再び非妊時の状㦔に湖次もどるものである，てのととは人乳腺のみな らず各種の動物にわたつても認め得る，物異的な生理的変化である。白鼠に於いても従来より組織学的研究 はなされているが，私は前述の如き実験目的より各時期に於ける乳腺の発育状態を，過去の文献上に見られ た粗な将期的分類に代えて，遂日的な検索を行つた，白鼠は短い期間中に著しい Hormon の変動があつて 乳腺もそれに相応して組織学的変化を来す。ての所見を基本として，本諭の $\mathrm{P}$ 実験により妊娠白鼠を相手と した，非妊白鼠の乳腺の変化に就いて内分泌学的見地加ら推察した。

\section{第 2 章 実驗材料及び実験方法}

1. 実験材料 実騟動物として兒鼠を使用した。 その筫択理由を挙げると次の如くである.

1) 白鼠の乳腺は通常 $5 \sim 6$ 対あつて ${ }^{13)}$ ，乙の各乳腺間に組織学的に殆どん差異がない. (後述)

2) 一部位の乳腺を切除するも他の部位に代償性增殖がない.

3） P実蹒に於いて白鼠が最も適した動物である。

4) 白鼠の尘理的諸現像が人類に非常に近い動物である ${ }^{199}$.

5) 成長期, 姃娠期, 産䝠期, 離乳期が短時日である。 
6) 繁殖が容易で，且つ妊娠日の判定がつく.

7) 各内分泌藏器の剔出実験が可能である。

実験に用いた白鼠は昭和28年以降教室で，近覾交配した 8 代以上の近交系 Wistar 系である。乙れはP実 験に於いて近交系及び同腹仔を使周するてとが原因不明と整死を防止出来たてとによる ${ }^{18)}$. 又，白鼠は原則 として処女白鼠を使用した。経産白鼠は時に処女白鼠との実驗比較として使用する程度にとどめた。

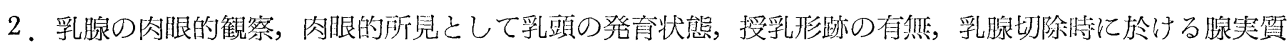
の発育状態及び腺実質切断時の乳汁証明等を挙げるととができる.

3. 乳腺切除法及び組緎検查法, 乳腺切除に際し白鼠にエーデル麻醉を施した。無麻醉でも切除は可能で あるが，乳腺を筋膜より分離して切除し且つ掑子等に上る皮下出血筞の副損㑺を避けるためには麻醉下に行

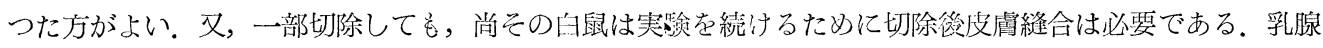
は乳頭直下が必ずしも発達していないため，乳頭を中心として約 $1.5 \mathrm{~cm}$ 平方の切除は必要である。乙の際筋

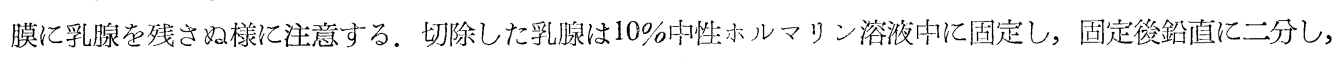
一部は Paraffin 切片を作り Haematoxylin-Eosin 重染色を施した。他の一部は氷結切片を作り Sudan III染 色を施した。切片は皮膚面に対し垂直になる様に切断した。

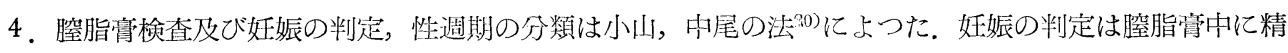

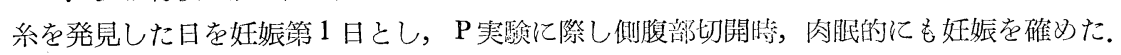

\section{第 3 章 一個体に於ける各乳腺の組織学的差異に就いて}

白鼠乳腺は左右 $5 \sim 6$ 対あり, 刖部 2 刘 $\left(\mathrm{T}_{1}, \mathrm{~T}_{2}\right)$, 腹鄐 1 対 $(\mathrm{Ab})$, 鼠蹊部 3 対 $\left(\mathrm{I}_{1}, \mathrm{I}_{2}, \mathrm{I}_{3}\right)$ あり,

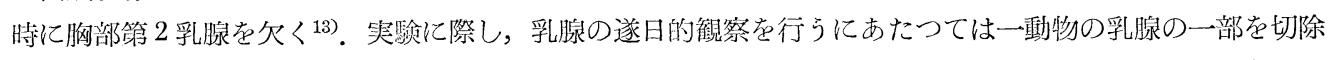
し，その組織学的差異の有無を梌索する必要があつた。彗験材料としては乳腺活動の特異的な時期と考えら れる妊娠 13 日，産裖 3 日，離乳鲑20日の乳腺を撰んだ。

1. 妊娠13日乳腺所見（第 1 表）

経産白鼠左側一側 6 個の乳腺を検索した。処女白鼠乳腺に於いて終胞腔は妊娠 16 日に出現する（後述）が， 経産であると娃娠13日で早くも全例に終胞腔を認めた。

肉眼的所見として, 乳頭の発育状態及び切除特乳腺実質は略々同様の所見を得た。乳腺切断時乳汁は認めら れない.

組織学的所見は第 1 表に示す如く全例に略々同様の所見を得た。腺葉は皮下脂肪組織の中に分葉著明に存 在し拡張した小排泄管，終末装笪，終胞腔上り構成されている。終胞腔は上皮内に脂肪小顆粒を認め，内腔 は中等度に拡張し少量の分泌物を認めた。間質は特に脂肪組織の発育がよく, 腺葉内毛細管は同様に拡張し ていた.

尚，ての自鼠で右下颚部に小さな乳頭状に隆起した部分を発見したので切除し検索した所，明らかに乳腺 であつたが上記 6 個の乳腺と全く所見を異にした。（附図 1 参照）即ち，中・小排渵管を小数認め，その周 囲に終末装置が開鎖して集合している形であるが小葉とは云い難い所見であつた。勿諭終胞腔は認められな い.

以上の所見加ら妊娠13日白鼠に於いては，各々の乳腺に組織学的差異は認称ない。しかし，所定以外の 部位に乳腺様組織を証明しても, その所見は学の時の生理洔期の乳腺組蟣像とは相一致し難し所見である.

\section{2. 産袮第 3 日乳腺所見（第 1 表）}

左右 6 対都合 12 個の乳腺を検索した。

肉眼的所見として，左胸部符II 孚腺乳頭に糜爛があり，他の乳腺と異つて授乳の形跡が見られなかつた。 (授乳された乳腺は, 乳頭が淡紅色で長さ $3 \sim 5 \mathrm{~mm}$ 亿発育肥大し, 乳頭を中心として径約 $1 \mathrm{~cm}$ 体毛か浮汁 で需れている.）又，切除將乳腺奏質は星的に少く，切断面よりの乳汁は認めない，他の11個の乳腺は授乳 の形跡あり, 乳頭の発育よく, 指圧により乳汁は小量であるが認められた。乳腺帮質は乳頭を中心として発 
第 1 表 同一動物乳腺比較

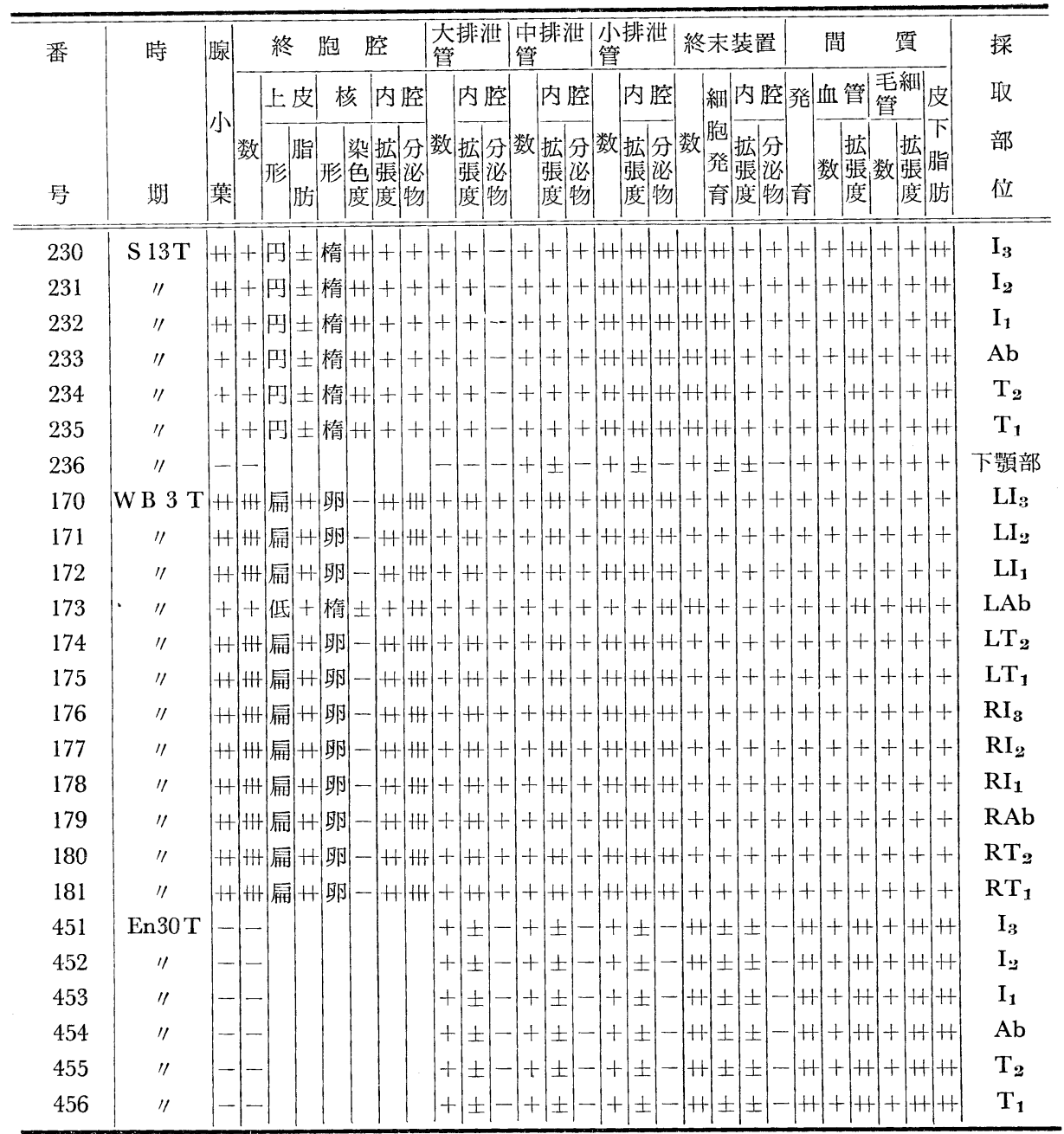

染色度, 淡 $(-)$, 稍淡 $(+)$, 稍濃 $(+)$, 浱 $(+t)$

円 $=$ 円柱上皮，低 $=$ 低円柱上皮，扁 $=$ 扁平上皮，棈 $=$ 楕円形，卵 $=$ 卵円形，類 $=$ 類円形

育良好で切断面より乳汁が認められた。

組織学的所見は符 1 表に示す如く，左胸部箱 II 乳腺（No. 173）（附図 2 参照）をのぞく他の11㑬の乳腺は 略々同椂の竘見であつた。即ち，乳腺発育状態では最も盛んな時期であり，終胞腔は高度に拉張し，上皮内 に脂肪顆粒を証明し，内腔に分泌物を証明した。間質部として証明する部位は少く脂肪組織も殆んど僅かで， 血管が殆んどその位置をしめている状態である。

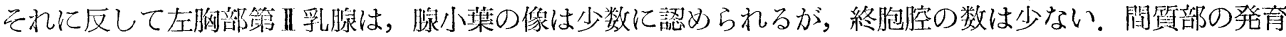
がよくて，充血も他の部位より著しい。

以上述べた加く，授乳期の乳腺を梌索するにあたつつ，先ず肉眼的所見で，乳頭の発育及び授乳の形跡の 有無を認觉必要がある。

3. 離乳後20日乳腺所見（節 1 表） 
右側の一側 6 個の乳腺について检索した。肉眼的所見にて乳頭は佲んど萎縮して扎り，乳頭下に乳頭下に

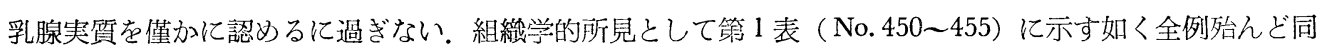
様の所見を得た。即ち，腺小葉及び終胞腔を認めず，間質部はよく発育し，その中に排泄管及び少数の終未 装置を認めた。

\section{第 4 算 正常性週期における乳腺所見}

白鼠処女乳腺は聞質脂肪組織内に比較的大きな排泄管を認めるに過ぎない，時としてその周团に僅ふれ小 排泄管及び終末装置を認める。併し，経産白鼠は処女白鼠に比較すると腺管の発育よく，小排泄管及び少数 の終末装置を認める事が出来る。

性週期の規則正しい処女並びそ経産白鼠を 5 日間毎日同一動物から乳腺を 1 個づつ切除して検索したが， 腺管部に著変なく，閜質部に於いて，角化期及び角化期の翌日に充血像，毛細管拡張が見られるがその他の 時期には特別に変つた所見を認めるてとが出来ね。

\section{第 5 章 妊娠期に於ける乳腺所見（第 2 表）}

白鼠の妊娠期間は21〜23日で妊娠日を確実に判定しても，妊娠期間は一定しない19)．ての実験に於いては 遂日的観察を主として行う為，なるべく同一動物を使用したかつたのであるが，前述した如く白鼠乳腺は左 右 5 〜 対であつて，妊娠期間中に同一動物を使用出来ない．その為同腹雌を用いた．乙の雌乳腺を妊娠 4 日目より 2 ～ 3 日の間隔で切除して観察し，てれによつて第 2 表に示す所見を得た。更に遂日的にその時期 の特徵ある所見を次に記載した。(括孤内は乳腺組織の番号を示したものである).

$\S$ 妊娠 4 日 閻質脂肪組織中に小排泄管が散在して，その周团に少数の終末装置を認める．腺管周囲に毛 細管抆張がある.

$\S$ 妊娠 5 日 間質脂肪組織の発育がよく，大・中排泄管周囲に小排泄管が数を堌している.

§妊娠 6 日 小排泄管周囲に終末装置が数個集団している。排泄管腔にエオデンに均等に染省る分泌物を 証明した。

§娃娠 7 日 前日と大差ない所見であるが終末装置がいくら加数を增している，分泌物は証明しない４ 4 例中 2 例 $(222 ， 374)$ は経産白鼠乳腺であるが，小排泄管周囲に終末装置が多く集り，不完全ではあるが小 葉形成が認められた。 小排泄管がよく拡張して分泌物を認めた。

§妊娠 8 日 中排泄管の拡張が著しい（383）間質の発育よく浮腫状（346）である．血管は拡張して充 血を認めた。

§妊娠 9 日 腺小葉はまだ不完全である。小排泄管腔に分泌物が認められる，上皮細胞原形質に脂肪小顆 䊀を認めた。 (379)

§ 妊娠10日 小排泄管とその周囲に十数個の終末装置が集り，略々小葉形成と考えられる．その周囲の毛 細管の拡張が顕著で間質結合織の発育もよい.

$\S$ 妊娠11日 分葉は著明であるが皮下は間質組織で大部を占めている，腺小葉は大小の差がある，小葉の 周囲に毛細管が数を増し拡張している。(340)

§妊娠12日 前日.の所見と大差はないが，終末装置が数を增して，分葉は著明に認められる。

$\S$ 妊娠13日 腺小葉は大部が終末装置より成り, 妊娠 9 〜 10日に比べると小排泄管腔は拡张し分泌物を証 明する。No. 231は経産白鼠であつて（第 3 章 1 参照）終胞腔を認め，処女白鼠と全く所見を異にしている。

§妊娠14日 閤質の発育よく，特に脂肪組織が增殖しているが，血管系はさほど充血を認めない，腺小葉 の発育はよいがままだ終胞腔を認めない。

$\S$ 妊娠15日 終胞腔はまだ認めないが，終末装置の発育よく，特に内腔側の上皮紐胞は低円柱状に発育し，

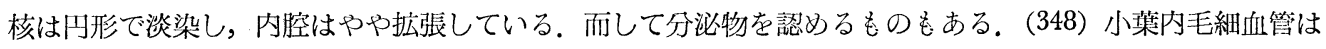
よく，拡張している. 
第 2 表 妊娠期乳腺所見

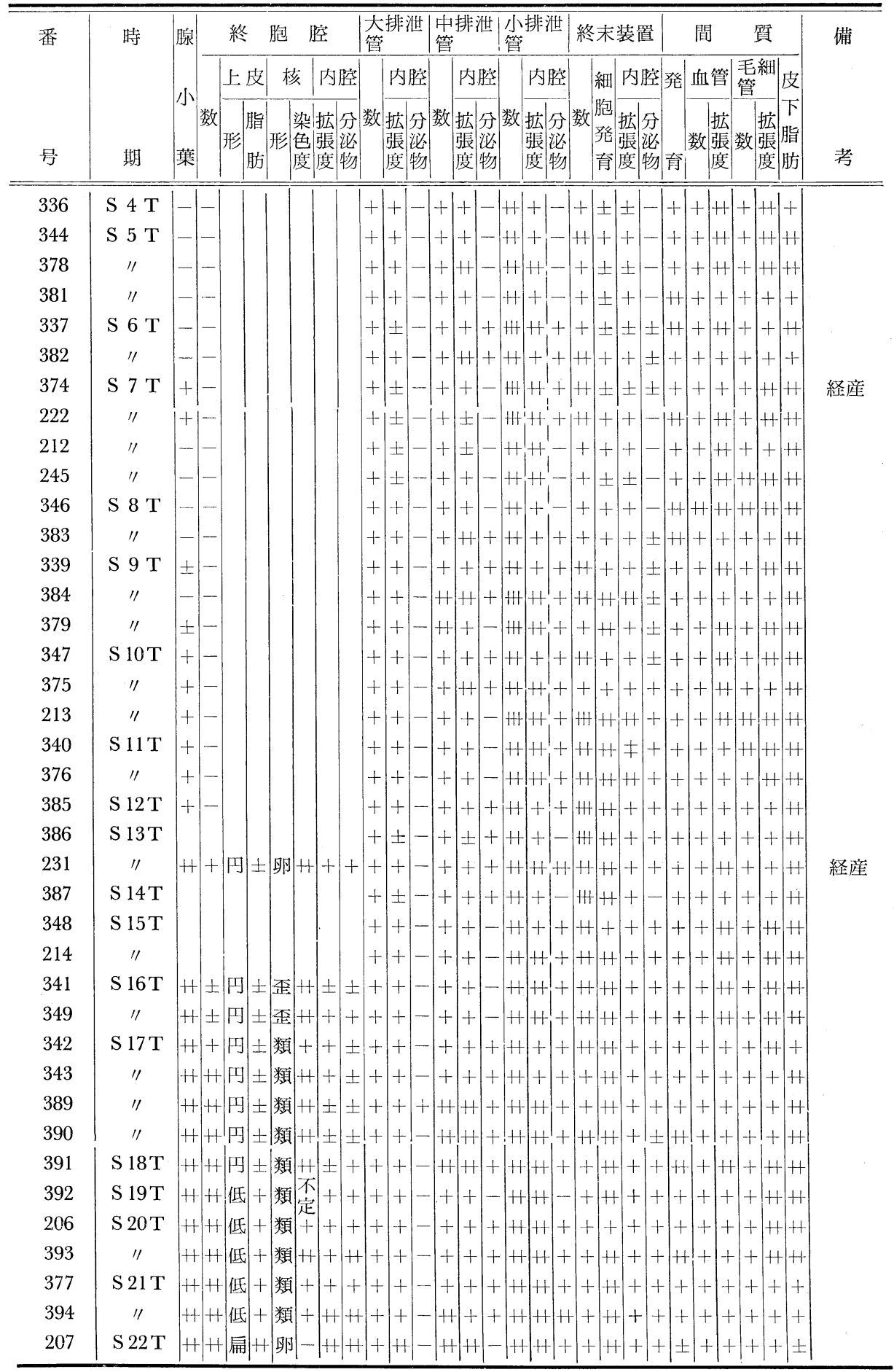


§妊娠16日 終胞腔を認める。一㬝の円柱上皮で，核は濃染して形は不正形である。終末装置の発育はよ く，特に内層の上皮細胞に著しい，小さい小葉が互いに接近しあい，処によつては合一している．前日以前 の所見に比べて間質が腺小葉の部分より狭くなつている。間質は殆んどが脂肪組織である。

§ 妊娠17日 終胞腔より成る小葉は，著明認められるが大小不同である．終胞腔上皮は低円柱状で核は 略々円形で濃染する。葉内毛細血管が著明に認められる。

§娃娠18日 前日と略々同椂の所見であるが，終胞腔内腔は稍々拡張して分泌物を証明する。エオジン好 染物質で脂肪反応陽性である.

$\S$ 妊娠19日 大きな腺小葉がその位置を占めて間質は量的に少くなつている，終胞腔上皮紐胞中の原形質 内に著明に脂肪顆粒が認められる。核は類円形で染色の程庴はまちまちである。内腔は拡張して分耖物を認 める.

§妊娠20日 腺小葉が増殖し，間質脂肪組織は量的に僅かである。終胞腔内腔が搪張している例と (393) 末だ拡張の著明でない例（206）が見られる。分泌物は前者に著明に認められ，後者は僅かに認めた。排泄 管はまだ拡張していない，間質は充血し，小葉内毛細血管の拡張が著しい。

$\S$ 妊娠21日 腺小葉は全く発育し全視野の大部分を占》, 間質は腺葉間を縫う如き状態で僅かである。脂 肪組綫も少い，符 2 表に示すての 2 例は（附図 $3 ， 4$ 参照）前日の例と同様に動物の例によつて終胞腔内腔

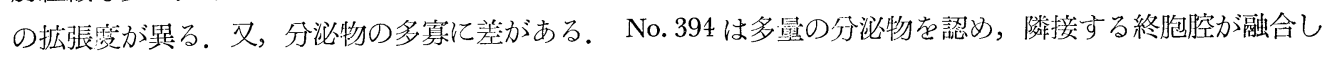

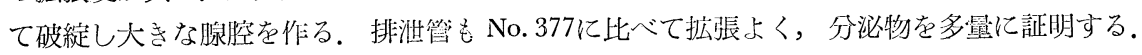

§妊娠22日（分婏㭙乳腺所見）間筫は全く亡くし，腺葉は排泄管を中心として拡張した終胞腔で大部を 占める。終胞腔上皮は低円柱又は扁平上皮で隣接する隔壁が破れて大きな腺腔を作る。核は卵円形で淡染す る. 排泄管は拡張しているが，大・中排泄管には未だ内容は認めない.

以上を要約すると，白鼠乳腺の娃娠性变化は妊娠 5 ～6 日より排泄管及び間質部の充血に始まる。続い て終末装置增殖（6７日），閻質部特に脂肪組織が発達する（７日） 8 9 日より中排泄管が稍々拡張し， 小排泄管及び終末装置が增殖して，10〜11日頃に腺小葉が形成される。以後腺小葉が増殖し閻質部がその量 を娍ずる。終胞腔は16日目に至つて認められ，始めて完全な腺小葉が形成される. 分泌現象は18１9日亿著 明となる，終胞腔の增殖，拡張と共に排泄管が拡張する。

\section{第 6 章 授䟭期に於ける乳腺所見（第 3 表）}

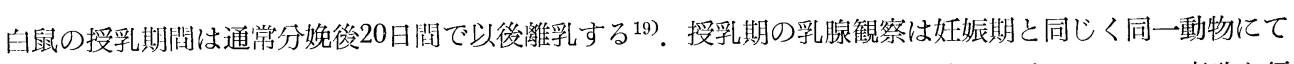
観察するのが望ましいととは言うまでもない.しかし授乳せる白鼠の乳腺を切除する時、エーテル麻醉を行 うと白鼠は授乳を中止するととがある。乙の事より同一動物を用いず個々別々の白鼠の乳腺を切除して観察 を行つた。 その特徴ある所見を次の第 3 表に記載する。

分婏時に於ける乳腺は前述の通り (207) 拡張した終胞腔に上る腺葉形成立びに排泄管拡張等授乳に対する 準備は既々完了している。

産裖 2 日には肉眼的に授乳された形跡を認妨，乳頭の発育も九く，肥大している。排泄管は総へて大きく 拡張し，腺小葉を形成する終胞腔は高度に拡張して大きな腺腔を作る。所謂網目状の腺腔を形成する.上皮 細胞は扁平或いは低门柱上皮で原形質の内腔側に脂肪顆粒を証明する。 又, 内腔縁の上皮細胞には細胞膜を 消失したが如く見られる部を諗める。核は大きな卵円又は梆门形で染色度は淡い. 間質部は小葉をとり囲 む程度に細く認められ，周囲の脂肪組絨は極めて僅かである。

産裖 3〜 5 日は産裖 2 日の所見とさ芯どの变化は認めないが，同一動物でも授乳の前後により，終胞腔上 皮の形, 質内脂肪顆粒の有無及び量, 内腔の分泌量等変化が見られる。

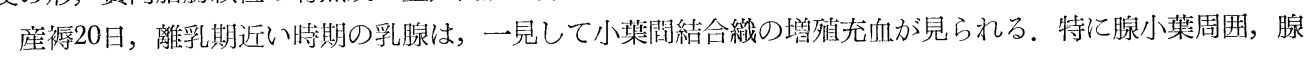
小葉内毛䋖血管の拡張が著明である脉小葉は稍々縮小しているが，排泄管には著変を認めない。

産褯21日，No.350は泌乳現象が盛んで，腺葉の網目状の所見が認められるが，腺葉自体は稍々縮小して 
いる，又，終胞腔上皮練胞核の形状及び染色庻がまちまちである．No. 141 は閭質結合織が增殖し，終胞腔 の縮小No. 350 上り著しい.

産裖35日，仔を離乳せずに飼育箱に同居させた産裖白鼠乳腺には泌乳現象を認めなかつた。即ち，腺小葉 は形成され，終胞腔は認められたが全く閉鎖した形である。一見終末装置との区別は困難であつた。 小葉内 に結合織が增殖し，血管特に毛細管の数は多く認められるが拡張は著明でない.

以上の如く，授乳期は妊娠期に発育した乳腺に泌孚作周か現われてくる。乙れは産裖 2 日目睡に著明に起 る. 即ち，終胞腔は高虔に拡張して大きな腺腔を作り，所謂網目状の腺組緎を形成する。上皮細胞は丈の低 い細胞になり，内腔側の細胞膜は破綻した如く見られ，内腔にェオジン好染物質及び脂肪顆粒を認める。排 泄管は娃娠期にも增殖発育するが，授乳期には更に発育し一首拡張する，授乳前後によつて多少異るが，通 常内腔に分必物を認める。䦞質結合織は亡しく，肥肪組織忌僅かである，しかし，離乳期近い産裖20日頃に なると，多くは腺小葉の縮小，間質結合織の堌殖が起きる。即ち，終胞腔上皮は円柱上皮になり，細胞内脂 肪顆粒は少く，核は小さく濃染する，内腔も縮小する，産裖35日では仔と同居しても授乳なく，又乳腺組織 にも泌乳現象を認められなかつだ.

第 3 表 産褯期及び授乳後離乳期乳腺所見

\begin{tabular}{|c|c|c|c|c|c|c|c|c|c|c|c|c|c|c|c|c|c|c|c|c|c|c|}
\hline 番 & & 腺 & & 終 & 胞 & 腔 & & & & & $\begin{array}{l}\text { 中排 } \\
\text { 管 }\end{array}$ & & $\begin{array}{l}\text { 小f } \\
\text { 管 }\end{array}$ & & & 末 & 装置 & & & 間 & 質 & \\
\hline 号 & 期 & 葉 & 列 & \begin{tabular}{|l} 
上皮 \\
脂 \\
形| 肪
\end{tabular} & & & 内腔 & & 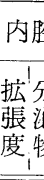 & & & $\begin{array}{l}\text { 勺腔 } \\
\text { 分 } \\
\text { 泌 } \\
\text { 物 }\end{array}$ & & 張济 & & \begin{tabular}{|l|} 
細 \\
胞 \\
発 \\
䏍
\end{tabular} & $\begin{array}{l}\text { 内胳 } \\
\text { 拡 } \\
\text { 張 } \\
\text { 度 }\end{array}$ & 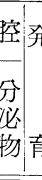 & & 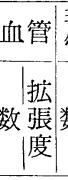 & $\begin{array}{l}\text { 毛細 } \\
\text { 管 } \\
\text { 数振 } \\
\text { 度 }\end{array}$ & $\begin{array}{l}\text { 脂 } \\
\text { 肪 }\end{array}$ \\
\hline 07 & 娩 時 & $H$ & $H$ & 扁 H & 卵 & & 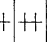 & + & H & & $+H$ & & $H+$ & $H+$ & + & H & $+1+$ & $+1 \pm$ & \pm & $+1+1$ & $+1+1$ & + \\
\hline 196 & $\mathrm{WB} 2 \mathrm{~T}$ & $\mathrm{H}$ & $H$ & 扁 & 楕 & $t+$ & ++ & + & $+t$ & & ++ & $H$ & $H-$ & $H+H$ & + & H & $H+$ & $+t$ & + & $+H+$ & $H H$ & + \\
\hline 194 & $\mathrm{WB} 2 \mathrm{~T}$ & $H$ & $H$ & 低 H & 楕 & $t+$ & $+H$ & + & $H+$ & + & $+H$ & + & $H$ & & $H$ & + & $+t$ & $+t$ & + & ++ & ++ & + \\
\hline 170 & W B $3 \mathrm{~T}$ & $\mathrm{HH}$ & m & 円 H & 楕 & $-H$ & $H+H$ & $H$ & $H+$ & $H+$ & $H H$ & $H$ & $H+$ & $H H$ & + & H & ++ & $+t$ & + & ++ & ++ & + \\
\hline 191 & WB $5 \mathrm{~T}$ & $H$ & $H$ & 低 H & 楕 & $t+$ & $+H$ & + & $H-$ & + & $+H$ & + & $H$ & $H+$ & + & + & $+t$ & $+t$ & + & ++ & ++ & + \\
\hline 197 & W B $20 \mathrm{~T}$ & ++ & +1 & 低 H & 楕 & + & +++ & + & $H-$ & + & $+H$ & + & + & $H+$ & + & + & $+t$ & ++ & $+t$ & $\mathrm{HH}+$ & $\mathrm{HH}$ & + \\
\hline 141 & W B $21 \mathrm{~T}$ & $H+$ & Ht & 陑 & 椅 & & $H+H$ & + & $H+-$ & + & $+H$ & + & + & $H+$ & + & + & $+t$ & $+t$ & + & $\mathrm{HH}+$ & $\mathrm{HH}+$ & H \\
\hline 350 & W B $21 \mathrm{~T}$ & $H$ & $H$ & 痈 + & 類 & tH & $H+H$ & + & $H+$ & H & $+H$ & $H$ & H & $\mathrm{HH}$ & + & $H$ & $+t$ & $+t$ & + & $+H$. & $+H$ & + \\
\hline 157 & W B $35 \mathrm{~T}$ & $H$ & $H$ & 円一 & 類 & $t \pm$ & $=-$ & + & + & - & ++ & + & $H$. & +- & H & + & +- & -+ & H & $H+$ & ++ & + \\
\hline 351 & En $2 \mathrm{~T}$ & + & +1 & 低 + & 類 & +4 & $+H$ & + & $H-$ & - & $+H$ & + & H & $H H$ & + & + & $H+$ & + \pm & \pm & $+H$ & $+H$. & + \\
\hline 352 & En $3 \mathrm{~T}$ & + & + & 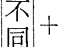 & \begin{tabular}{|l|} 
不 \\
同
\end{tabular} & EH & H & + & $H-$ & - & $+H$ & - & H & $H+$ & H & + & +1 & $+t$ & + & $\mathrm{HH}+$ & $\mathrm{HH}+$ & H \\
\hline 142 & En $3 \mathrm{~T}$ & $H$ & +1 & 低 + & 棈 & & $H+H$ & + & + & 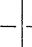 & $H+H$ & $H$ & H & $H H$ & + & + & $H+$ & $+t$ & + & $+H+t$ & $\mathrm{H} H$ & + \\
\hline 35 & $\mathrm{~T}$ & + & +1 & & \begin{tabular}{|l|} 
不 \\
同
\end{tabular} & & $H+H$ & + & + & & & + & $H$ & & H & + & + & & & $H+H$ & $H+H$ & H \\
\hline 354 & $5 \mathrm{~T}$ & + & + & & & + \pm & $5-$ & + & + & & ++ & - & + & + & $H$ & + & t & 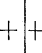 & H & & $\pi+t$ & H \\
\hline 143 & En $5 \mathrm{~T}$ & $H$ & + & 低 - & $\begin{array}{l}100 \\
\text { 棈 } \\
\end{array}$ & $t \pm$ & $t+$ & + & + & - & ++ & - & $H$ & $H+$ & + & + & + & + & $H$ & $+H+t$ & $H+H$ & H \\
\hline 144 & En $6 \mathrm{~T}$ & $H$ & + & 低 - & 棈 & & $t+$ & + & + & - & ++ & - & H & $+H$ & + & + & $H$ & $+t$ & & $++t$ & $H+$ & + \\
\hline 35 & En $6 \mathrm{~T}$ & + & - & & & & & + & + & - & ++ & + & + & & $H$ & + & + & $T$ & & $H H+$ & $\mathrm{H}+\mathrm{H}$ & H \\
\hline 356 & En $7 \mathrm{~T}$ & + & - & & & & & + & + & & ++ & - & + & +- & $H$ & + & + & 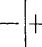 & H & $+H$ & $+H$ & $H$ \\
\hline 357 & En $8 \mathrm{~T}$ & \pm & - & & & & & + & +- & - & ++ & - & + & + & $H$ & + & + & 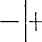 & H & $+H$. & $+H$ & H \\
\hline 358 & $\mathrm{En} 9 \mathrm{~T}$ & \pm & - & & & & & + & +- & 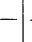 & ++ & - & + & + & + & + & t & 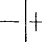 & & $+H$. & +++ & H \\
\hline 359 & En10T & \pm & - & & & & & + & + & & ++ & - & + & +- & + & + & \pm- & & 1 & ++ & ++ & + \\
\hline 360 & $\mathrm{En} 12 \mathrm{~T}$ & \pm & - & & & & & + & + & 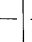 & ++ & - & + & +- & + & + & & - & + & ++ & ++ & + \\
\hline 361 & En14T & \pm & & & & & & + & + & & ++ & - & + & +- & + & + & & 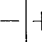 & & ++ & ++ & + \\
\hline 145 & En14T & + & & & & & & +1 & + & & + \pm & & + & & & \pm & $\pm 1-$ & & & $+H$ & $+H$ & . \\
\hline
\end{tabular}




\section{第 7 章 離乳期の乳腺所見}

授乳白鼠は通常分娩後 21 日で離乳する ${ }^{199}$ 。離乳期乳腺といえば一定の授乳期間後に離乳して乳腺をさすの であるが，私は本研究に於いて，分婏後授乳させずに直ちに離乳させた乳腺も検索し比較検討を行つた。

材料は授乳後離乳は産症21日以後，分娩捘離乳は分婏捘直ちに仔を離した自鼠の乳腺を遂日的に切除して 検索した。

1. 授乳後離乳乳腺所見 (第 3 表)

§離乳後 2 日 離乳時に見られた拡張した腺腔は12 1 13位に縮小し，終胞腔上皮は低円柱或いは円柱上皮 に変り，内腔側細胞膜が明瞭に認められるものが多い，細胞内脂肪顆粒は尚かなり大きな顆粒を証明する。

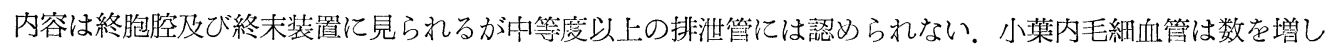
著しく拡張する。

§離乳後3 日 終胞腔はまだ拡張し，分泌物を認める。中には腺腔が丸なり閉鎖しているものも見られる。

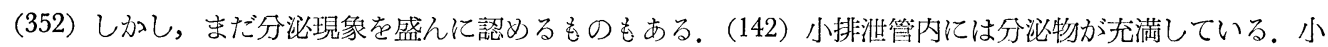
葉䦬結合織の增殖及び毛細血管の㧒張は著明である。

§離乳後 4 日 腺小葉の終胞腔の状態が各小葉により全く異り一定していない，即ち，全く萎縮したもの

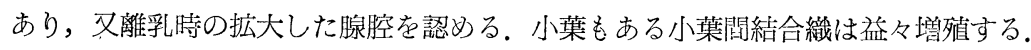

§離乳後 5 日 終胞腔は閉鎖状で数が少い，終胞腔上皮細胞核は焱染する大きな円形のものと濃染する小 さな棈门形の二種が見られる。（143）腺腔の内容は滒脱した上皮細胞を少し認めるもの(143) 又，認めない もの (354) もある。葉閖結合織は增殖して，脂肪組織も著明である。排泄管は小排泄管のみに内容を認め る.

§離乳後6 日 腺小葉は大部分が小排泄管，少数の終末装置で構成されていて，終胞腔を認め得るもの (144)，及び認め得ないものと (355) ある。閥質結合織の增殖著しく，小葉内に結合織の増殖をみる (144).

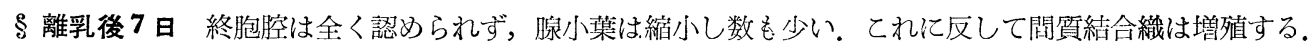
拂泄管に内容を認めず，閉鎖状である。闑質は血管の発育が尚著明である。

$\S$ 離乳後 8 日以後腺小葉は益々萎縮し，乙れに反して開質部は增殖する。腺小葉は小排泄管及び終末装 置で構成されている。排泄管は閉鎖状になり，終末装置は発育悪く内腔は閉鎖する。

以上の如く授乳後離乳乳腺は離乳時に既に産裤 $3 \sim 5$ 日の活動期より退潮している. 而して離乳翌日には 急にその腺腔が縮小する。終胞腔上皮細胞の形状は丈が高くなり，乳汁は大・中排泄管には認められない。 終胞腔は遂日的に萎縮するが，内腔の拡張程度は各小葉卡り異つて一様でない，離乳後 5 日に大部分が閉 鎖するようである。離乳後 7 日以後は終胞腔を証明せず。排泄管の内容は 4 日目迄は中・小排泄管に著明に 認妨えるが，7 日以後には証明出来ない，腺小葉は菱縮，縮小する経過をとるが，てれに反比例するが如

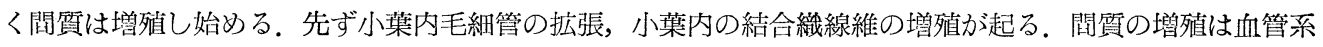
より始まり，結合織特に脂肪組織が次符に発育し，8－9日頃の閏質部の增殖が著しい．10日以降は毛細血 管の拡張はさほど著明でなくなる。而して，離乳後14日では腺小葉も認められず，排泄管及び終末装置は閉 鎖し数も少くなり，静止状態の乳腺と考元られる.

2. 分婏後離乳乳腺所見 (第 4 表)

$\S$ 分婏後 2 日 終胞腔は高庴に拡張し, 腺組繊の網目状構造が見られ, 内腔は分泌物で充満する。排泄管 き発育よく，内腔にも亦分泌物が充満している，間質部は亡しく主として血管性で，特に毛練血管の拡張が 著しい。

§分婏後3 日 腺腔は稍々狭くなつているが前日の所見と大差がない，只間質部の充血が著明である.

§分婏後 4 日 分葉は著明であるが，腺小葉は縮小している。 まだ終胞腔の半数位は拡張していて内容を 認める，終胞腔上皮細胞の核が前日に比べて濃染している，小葉閂結合織が稍々增殖する，充血は养々著明 である. 
第 4 表 分娩後離乳期乳腺所見

\begin{tabular}{|c|c|c|c|c|c|c|c|c|c|c|c|c|c|c|c|c|c|c|c|c|c|c|c|}
\hline \multirow{3}{*}{$\begin{array}{l}\text { 番 } \\
\\
\text { 号 }\end{array}$} & \multirow{3}{*}{$\begin{array}{l}\text { 時 } \\
\text { 期 }\end{array}$} & \multirow{3}{*}{ 小 } & \multicolumn{4}{|c|}{ 終＼cjkstart胞 } & \multicolumn{2}{|c|}{ 腔 } & \multicolumn{2}{|c|}{$\begin{array}{l}\text { 大排泄 } \\
\text { 管 }\end{array}$} & \multicolumn{3}{|c|}{\begin{tabular}{|l} 
中排泄 \\
管 \\
\end{tabular}} & \multicolumn{2}{|c|}{$\begin{array}{l}\text { 小排泄 } \\
\text { 管 }\end{array}$} & \multicolumn{3}{|c|}{ 終末装置 } & \multicolumn{3}{|c|}{ 間 } & \multicolumn{2}{|l|}{ 寶 } \\
\hline & & & & 上皮 & 格 & & 内肚 & & & 内腔 & & 内 & 腔 & & 内腔 & & & 内腔 & 発 & 血 & 管|事 & 毛細|皮 & 皮 \\
\hline & & & & 肪 & & 染 & $\begin{array}{l}\text { 拡 } \\
\text { 張 } \\
\text { 度 }\end{array}$ & & & 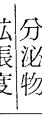 & & & $\left|\begin{array}{l}\text { 分 } \\
\text { 泌 } \\
\text { 物 }\end{array}\right|$ & & 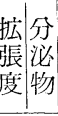 & & $\begin{array}{l}\text { 胞|找 } \\
\text { 発表 } \\
\text { 表 }\end{array}$ & & & $\left.\right|^{2}$ & $\mid \begin{array}{l}\mid \text { 拡 } \\
\text { 張数 } \\
\text { 度| }\end{array}$ & 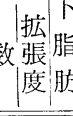 & $\begin{array}{l}\text { 脂 } \\
\text { 肪 }\end{array}$ \\
\hline 207 & 分婏 時 & $H$ & & & & - & & & $+t$ & +- & + & + & & 17 & $H \pm$ & & H & ++ & \pm & & ++ & ++ \pm & \pm \\
\hline 327 & $\mathrm{G}$ 後 $2 \mathrm{~T}$ & $\mathrm{HH}$ & $H$ & 低 + & 棈 & - & $H+$ & & +- & + & t & & $+t$ & $H$ & $H+H$ & + & + & ++ & \pm & & $+H+$ & $+H+$ & + \\
\hline 328 & $\mathrm{G}$ 後 $3 \mathrm{~T}$ & $H$ & $H$ & 低 + & 楕 & \pm & $H+t$ & & +- & + & + & + & & H & & + & + & +1 & \pm & & $+1+$ & ++++ & + \\
\hline 329 & $\mathrm{G}$ 後 $4 \mathrm{~T}$ & $H$ & + & 低 + & 棈 & + & + & & +- & + & + & + & + & H & & + & + & ++ & + & -1 & $H+$ & $+H+$ & + \\
\hline 315 & $\mathrm{G}$ 後 $4 \mathrm{~T}$ & $H$ & + & 低 + & 棈 & $H$ & $H+t$ & & +- & $+H$ & + & & & $H+$ & & + & $H$ & $H+$ & $-H$ & ++ & $H+$ & +++ & + \\
\hline 318 & $\mathrm{G}$ 後 $5 \mathrm{~T}$ & + & + & 低 + & 棈 & $H$ & +1 & & +- & $++t$ & + & & $H$ & H & $H H$ & + & $H$ & $H+H$ & $H$ & ++ & $+t$ & +++ & H \\
\hline 330 & $\mathrm{G}$ 後 $5 \mathrm{~T}$ & $H$ & + & 円 - & 棈 & $H$ & + & & +- & $t+$ & + & & + & + & ++ & $H$ & + & ++ & + & & $H+$ & $+H+$ & + \\
\hline 331 & $\mathrm{G}$ 後 $6 \mathrm{~T}$ & + & + & 円- & 棈 & $H$ & $\pm=$ & & +- & ++ & + & + & + & + & ++ & H & + & & & ++ & $+t$ & $++t$ & + \\
\hline 332 & $\mathrm{G}$ 後 $8 \mathrm{~T}$ & + & - & & & & & & + & +- & + & + & + & $H$ & & $H$ & + & +- & & -+ & $+1+$ & +++ & + \\
\hline 333 & $\mathrm{G}$ 後 $10 \mathrm{~T}$ & + & - & & & & & & +- & ++ & + & + & + & + & ++ & $H$ & + & & & & $H+$ & $++t$ & + \\
\hline 334 & $\mathrm{G}$ 後 $11 \mathrm{~T}$ & \pm & - & & & & & & + & +- & + & + & + & + & ++ & $H$ & + & & & & $H+t$ & +++ & + \\
\hline 209 & $\mathrm{G}$ 後 $13 \mathrm{~T}$ & + & - & & & & & & + & +- & 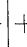 & + & & $H$ & +- & $H$ & + & + & & & $H+$ & $++t+$ & t+ \\
\hline 335 & $\mathrm{G}$ 後 $13 \mathrm{~T}$ & \pm & & & & & & & + & +- & & & & & + & $1+$ & \pm & & & & $+1+$ & $+1+1$ & + \\
\hline
\end{tabular}

§ 分婏後 5 日 腺小葉は縮小している。終胞腔は殆んど閉鎖している。しお拡張して分泌物を認めるも のもある.(318) 排泄管は閉鎖せず比較的大きな排泄管で乳汁の残溜を認、葉閆の結合織が增殖し， 又毛細組管の拡張著明，間質部は稍々浮腫状である。

§ 分婏後 8 日 腺小葉は認められるが，終胞腔は認められない，排泄管は大・中排泄管は開鎖状であるが， 中排泄管で内容を僅が誌めるものもある。小排泄管及び終末装置は腺小葉を構成するが縮小が著明である。 腺小葉内に結合織か增殖している，間質部は腺小葉の菱縮に反比例して発育する。

§ 分婏後10日 分葉は不明膫で大・中排沺管周囲に点在する。終胞腔は認められない，排泄管のなか子には 未だ開鎖せずに拡張して内容を証明するものきある。開質部は允血している。

§分婏後11日 腺小葉は全く萎縮し，乙れに代つて，閪質結合織が增殖する。中・小排泄管は拡張して内 容を証明する。

§ 分婏後13日 分葉は稍々著明に認められるものもあるが，各小葉を構成している，小排泄管は稍々拡張 し，発育の悪い終未装置と一緒になつて腺小葉を構成している。（209）しかし No. 335 は全く分葉不明膫で ある。而して排泄管も閉鎖状で内容を認められない。

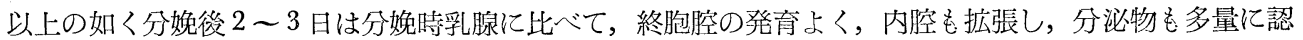
められる，又，いずれの排泄管も拉張し分泌物を充満している。䦗質の充血が著明である。併し，分婏後 4 日に至つて腺葉の縮小，内腔の閉鎖が始り，次管に菱繀経過をとり，分婏後 8 日以降に終胞腔は認められず， 又腺小葉气分婏捘11日以捘は不明膫となる。乙れに刘して間質部は分婏捘 4 日以降次第に增殖して，腺小葉 とその立場を変ずる如く発育する。排泄管は前項の授乳後離乳の場合と異り，排泄管の閉鎖立びに内腔の分 泌物が比䡴的長期に亘つて証明するてとが出来る。

以上の如く授乳後離乳と分婏後髉乳の乳腺を比較梌討すると，腺小葉，腺腔の縮小はさほどの相違点はな く，終胞腔の消失も同じく7 日目頃と考察出来るが，排泄管の所見に差異があり，授乳後盛乳の場合は大排

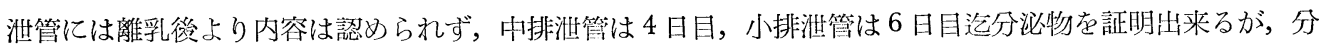
婏後離乳の場合は大排泄管は10日目，中・小排泄管は11日目汽拡張して内容を証明出来た， 


\section{第 2 編 妊娠白鼠老用いたP実験による乳腺の研究}

\section{第 1 章 実 験 要 旨}

妊娠時体内に循環する Hormon 研究の一端として, 私は従来 $\mathrm{P}$ 法を用いた灵驗的研究を行つて来た。 P

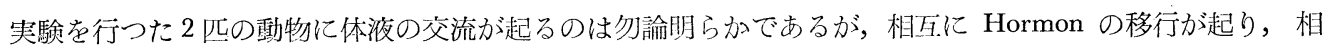
手側に必ずしも影響を与えるとは限らない，徒来よりの斫究によるに同性或いは異性間 $\mathrm{P}$ 於いては，相互 生殖腺に変化を認め妨とになつている32,25)。乙れは相互の正常成熟動物に於いては，相手側に変化を及ば す有効量の Hormon 分泌がないと解釈されている。此の点に関して既に当教室に於いて久保田が成熟・幼 弱白鼠 $\mathrm{P}$ 実験を行い相当の影響のあるととを明らかにした ${ }^{18)}$. また本禺験もこの点に関して影響の有無を知 る好箇の実験であるととは言うまでもない，即ち，相手侧（非姃側）に変化を来すととは，妊娠した動物 (本実験に於いては白鼠) 体内に過剩分泌 Hormon の存在を証明与ることになり，妊娠側よりの移行した Hormon が，非妊側に影響を及ばすに足る有效量の Hormon のあるととを明らかに知ることが出来た。

この影響を知るために，非弤侧の乳脉の恋化を遂日的に組織学的に観察を行つたが，乳腺が姃娠により短 時日に特異な変化を来し，而して外表より遂日的に観察するてとが可能で且つ簡易に切除出来る。乙れ等の 利点を利用して相手側非妊十鼠を成熟䧳と去勢雌の二通りに分けて観察した。乙れによつて成熟側の卵巣の 態度並びに去勢側の脳下重体の態度に就いても考察した。

\section{第 2 章 実験材料並びに実験方法}

使用白鼠は前編で記した如く当教室で飼育した Wistar 系処女白鼠を用いた，使用白鼠の体重は一律に平 均したものを使用出来ず，100～200g の閐のものを使用した，Pの組合せをする 2 匹は同腹で体重の近いも のを撰び，その際，相手側の门鼠を妊娠側より約 $20 \mathrm{~g}$ 重いものを撰んだ。これは妊娠が進むととによつて妊

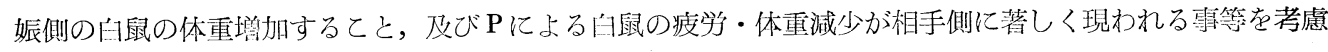
したためである。

去勢白鼠は去勢手術後 2 週以上の経過したもので，使用前少くとも5 日間腔脂毫検査を行い，間期の持続 を確認してから使用した.

P 手術法は小山氏法に準じ ${ }^{19)}$ ，皮膚䈈肉腹膜縫合法にて行つた。この際，縫合する手術創は皮膚 $5 \mathrm{~cm} ，$ 腹

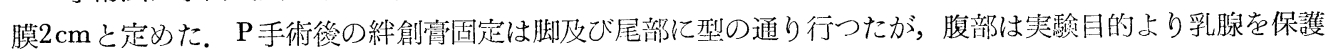
するため，门 $2 \mathrm{~cm} の$ 紏創高を胸部並びに腹部に各々一条行い，腹部の方は弤娠側の腹部圧迫に留意した。手 術時の麻酔は Thiopental sodium $5 \mathrm{mg} /$ 体重 $100 \mathrm{~g}$ 腹腔内注射によつた.

実験方法は子好妊娠させた自鼠が，弤娠 7〜8 日になるのを待つて，その相手に妊娠自鼠上り体重が略々 $20 \mathrm{~g}$ 重い同腹の雌（成熟及び去勢雌）を撰んで $\mathrm{P}$ 手術を行つた。乳腺切除は $\mathrm{P}$ 時及び $\mathrm{P}$ 後 5 日目より $3 \sim 4$ 日間隔に切除し，妊娠側の分娩前日に 2 匹を離解することを原則とした.

\section{第3章 相手白鼠を成熟此した実験}

\section{P実験成綪}

妊娠白鼠と成熟雌自鼠との $\mathrm{P}$ 組合せは 30 組行つた。（術後 2 日以内に死亡した組合せは含まない） $\mathrm{P}$ 奏験 には原因不明で贸死する事が多く，30例中 5 日以内死亡した例は14例ある。この死亡は相手侧目鼠が12例， 双方共死亡したものが 2 例，妊娠側占鼠が死亡した例はなかつた。

$\mathrm{P}$ 実験が 5 日以上持続した場合は，体重が極度に減少する壯をのぞいて，妊娠側が分娩する迄 $\mathrm{P}$ は持続し た.

妊娠側の弤娠期間の变動は見られない.

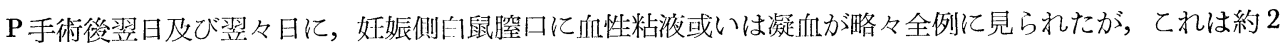

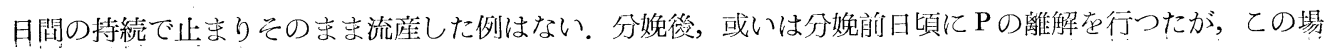


合相手側白鼠は疲学度劇しく死亡した例が多い。

2. P 後の遂日的観察による乳腺所見（第 5 表）

第 5 表 $P$ 実験成熟雌乳腺所見

\begin{tabular}{|c|c|c|c|c|c|c|c|c|c|c|c|c|c|c|c|c|c|c|c|c|c|c|c|}
\hline \multirow{3}{*}{$\begin{array}{l}\text { 番 } \\
\text { 号 }\end{array}$} & \multirow{3}{*}{\multicolumn{2}{|c|}{ 時 }} & \multirow{3}{*}{$\begin{array}{c}\text { 腺 } \\
\text { 小 } \\
\text { 葉 }\end{array}$} & \multirow{3}{*}{ 終 } & \multicolumn{3}{|c|}{ 大排泄管 } & \multicolumn{3}{|c|}{ 中排泄管 } & \multicolumn{3}{|c|}{ 小排泄管 } & \multicolumn{4}{|c|}{ 終末装置 } & \multicolumn{3}{|c|}{ 間 } & \multicolumn{3}{|c|}{ 質 } \\
\hline & & & & & \multirow[b]{2}{*}{ 数 } & \multicolumn{2}{|c|}{ 内腔 } & \multirow[b]{2}{*}{ 数 } & \multicolumn{2}{|c|}{ 内腔 } & \multirow[b]{2}{*}{ 数 } & \multicolumn{2}{|c|}{ 内腔 } & \multirow[b]{2}{*}{ 数 } & \multirow{2}{*}{$\begin{array}{l}\text { 細 } \\
\text { 胞 } \\
\text { 発 } \\
\text { 育 }\end{array}$} & \multicolumn{2}{|c|}{ 内腔 } & \multirow{2}{*}{$\begin{array}{l}\text { 発 } \\
\text { 育 }\end{array}$} & \multicolumn{2}{|c|}{ 血管 } & \multicolumn{2}{|c|}{ 毛細管 } & \multirow{2}{*}{\begin{tabular}{|c} 
皮 \\
下 \\
脂 \\
肪
\end{tabular}} \\
\hline & & & & & & 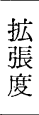 & $\begin{array}{l}\text { 分 } \\
\text { 泌 } \\
\text { 物 }\end{array}$ & & 摭 & 分 & & 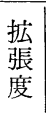 & $\begin{array}{l}\text { 分 } \\
\text { 泌 } \\
\text { 物 }\end{array}$ & & & $\begin{array}{l}\text { 拡 } \\
\text { 㲀 } \\
\end{array}$ & $\begin{array}{l}\text { 分 } \\
\text { 泌 }\end{array}$ & & 数 & $\begin{array}{l}\text { 拡 } \\
\text { 浱 }\end{array}$ & 数 & & \\
\hline 217 & & $4 \mathrm{~T}$ & - & - & - & \pm & - & + & \pm & + & + & \pm & - & + & \pm & + & - & + & + & $H$ & + & $H$ & + \\
\hline 226 & " & & - & - & + & + & - & + & + & - & H & + & \pm & $H$ & $H$ & + & \pm & + & + & $H$ & + & + & + \\
\hline 229 & & $5 \mathrm{~T}$ & - & - & + & \pm & - & + & \pm & - & + & \pm & - & + & \pm & - & - & + & + & $H$ & + & $H$ & + \\
\hline 458 & "I & & - & - & + & + & - & + & + & + & + & + & + & + & \pm & \pm & \pm & + & + & $H$ & + & + & H \\
\hline 461 & "I & & - & - & + & t & - & + & + & - & + & + & - & + & \pm & + & - & + & + & H & + & + & + \\
\hline 472 & "1 & & - & - & + & + & - & + & + & - & + & + & - & $H$ & + & + & - & +1 & + & H & + & $H$ & $H$ \\
\hline 474 & "I & & - & - & + & + & - & + & + & - & \pm & + & + & + & + & + & + & + & + & $H$ & + & $H$ & H \\
\hline 302 & "1 & & - & - & + & + & - & + & + & - & + & \pm & - & + & \pm & \pm & - & + & + & H & + & $H$ & H \\
\hline 320 & "I & $6 \mathrm{~T}$ & - & - & + & \pm & - & + & \pm & - & + & + & - & + & \pm & \pm & - & + & + & + & + & $H$ & + \\
\hline 475 & " & & - & - & + & + & - & + & + & - & H & + & + & + & + & + & + & + & + & H & + & $H$ & $H$ \\
\hline 477 & " & "I & \pm & - & + & + & - & + & \pm & - & + & + & - & H & \pm & \pm & - & + & + & + & + & $H$ & $H$ \\
\hline 459 & "1 & $9 \mathrm{~T}$ & - & - & + & + & - & + & 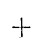 & + & H & H & + & + & $H$ & + & + & + & + & H & + & $H$ & + \\
\hline 462 & "I & & - & - & + & + & - & + & $H$ & + & + & $H$ & + & + & + & + & + & + & + & $H$ & + & $H$ & + \\
\hline 218 & "1 & $10 \mathrm{~T}$ & + & - & + & \pm & - & + & + & - & + & + & + & + & + & + & + & + & $H$ & $H$ & $H$ & $H$ & + \\
\hline 227 & " & & + & - & + & + & - & + & $H$ & + & H & $H$ & + & + & + & + & + & + & $H$ & $H$ & H & $H$ & + \\
\hline 296 & " & "I & \pm & - & + & + & - & + & + & + & $H$ & + & \pm & $H$ & \pm & \pm & \pm & + & + & $H$ & $H$ & $H$ & H \\
\hline 321 & " & $12 \mathrm{~T}$ & \pm & - & + & + & - & + & \pm & - & $H$ & H & + & + & $H$ & + & + & + & + & $H$ & $H$ & $H$ & \pm \\
\hline 463 & " & $13 \mathrm{~T}$ & - & - & + & + & - & + & $H$ & + & + & $H$ & + & + & $H$ & $H$ & + & + & + & H & + & $H$ & + \\
\hline 324 & " & & \pm & - & + & + & - & + & \pm & + & $H$ & + & + & + & + & + & + & + & + & H & $H$ & $H$ & \pm \\
\hline 219 & "I & $14 \mathrm{~T}$ & + & - & + & + & - & + & + & - & H & + & \pm & $H$ & $H$ & H & + & + & + & $H$ & $H$ & $H$ & H \\
\hline 478 & " & $15 \mathrm{~T}$ & \pm & - & + & \pm & - & + & \pm & - & + & + & + & $H$ & + & + & + & + & + & $H$ & + & + & + \\
\hline 220 & " & $16 \mathrm{~T}$ & \pm & - & + & \pm & - & + & \pm & - & $H$ & + & - & $H$ & $H$ & + & - & + & + & + & + & + & H \\
\hline 464 & " & & H & - & + & + & - & + & + & - & H & + & - & $H$ & \pm & - & - & $H$ & $H$ & $H$ & + & $H$ & H \\
\hline 303 & " & $17 \mathrm{~T}$ & - & - & + & + & - & + & + & - & $H$ & \pm & - & + & \pm & \pm & - & + & + & $H$ & + & + & \pm \\
\hline 305 & " & $19 \mathrm{~T}$ & - & - & + & + & - & + & + & - & + & \pm & - & + & + & + & - & + & + & + & + & $H$ & \pm \\
\hline 307 & " & $23 \mathrm{~T}$ & - & - & + & + & - & + & \pm & + & $H$ & \pm & + & + & + & + & + & \pm & + & + & + & $H$ & \pm \\
\hline
\end{tabular}

\section{$\S P$ 後 4 日}

No. 217 特別な所見は見られない，只間質部の血管系の充血毛細血管の拡張が見られる.

No. 226 経産白鼠であるため $\mathrm{P}$ 㭙に小排泄管及び終末装置を認めた。即ちての乳腺では腺管に特別の変化 が見られない．而してNo. 217 と同じく間質部に変化を認めたのみである.

\section{$\S P$ 後 5 日}

No. 229 䦭質部の充血の他所見がない.

No. 302 中排泄管の周囲に小排泄管及び終末装置が点在する. 間質部毛細血管の增殖及び挔張著明である.

No. 458 小排泄管の增殖著明，その数に比べて終末装置は少い. 小・中排泄管の管腔に上皮細胞の剝脱し たものを認めた。 
No. 461 小排泄管の增殖あり, 又終末装置も增殖しているが発育末だし.

No. 474 脂肪組織堌殖, 終末装置 $5 \sim 8$ 個集り，その周囲の毛細血管が拡張している. 小排泄管はさほど 多くない.

\section{$\S P$ 後 6 日}

No. 320 大・中排泄管は閉鎮状，小排泄管は梢々拡張して，終末装置も増殖している.

No. 475 小排泄管の堌殖著明，内腔に上皮細胞を認める。閆質脂肪組織が可良である.

No. 477 脂肪組織の発育良，ての中に閉鎖した排泄が散在している。 この周囲に終末装置が小さな集団を なしている.

\section{\& 後 9 日}

No. 459 小排泄管は其の数を增し，内腔に剝脱した上皮細胞を認める。終末装置は No. 458 ( $\mathrm{P}$ 後 5 日) より数を増しているがさほど多くない，全体の発育よくて，内腔は拡張し，内容を僅かに証明する，(附図 5 参照)

No. 462，No. 459 と同じく中・小排泄管は数を增し，特に中排泄管は高度に拡張し，内腔にェオシン好染 物質の存在を諗める。しかるに終末装笛の数は少い，間質部の充血が著しい。

\section{$\S \mathrm{P}$ 後10日}

No. 218 大・中排泄管を中心として小排泄管が堌殖している，分葉は著明で終末装置の発育がよい，内腔 拡張し内容を認める。閵質部の発育もよく充血し，毛細血管が拡張する。（附図 6 参照）

No. 227 経産白鼠であるが，中排泄管多数あり高度に拡張して内容を有する。排泄管をのぞく他すべて 内容を認邓る。脂肪染色陽性物質である。終末装置の数は少いが，小革を形成する，小葉内に結合織か溌達 し，血管に富み，毛細血管の拡張が見られる。

No. 296 閪質脂肪組織内に小さな腺小葉が散在する。乙の腺小葉は小排泄管が多い，乙れを囲んで終末装 置が小数集つている.内腔江分泌物を僅汃証明する.

\section{$\S P$ 後12日}

No. 321 分葉はあまり著明でないが，小排泄管及び終末装置が集つて形成されている，小排泄管は数が多

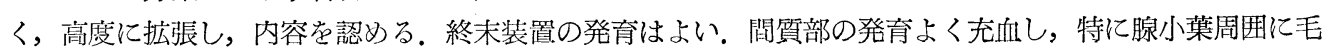
細血管を多数認める.

\section{§ $P$ 後13日}

No. 463 中・小排泄管は高度に抁張し，内腔に分泌物を証明する。乙の中に上皮細胞を認める終末装置は 数は少いが発育よく, 内腔は拡張する，分葉はあまり著明でない，毛細血管の拡張著しく，間質部の充血が 著しい. (附図 7 参照)

No. 324 小排泄管が多く認められて，乙の周囲に終末装置がある。両方とも内腔の拡張はあまり見られな い.内容を証明する。

\section{\& P 後14日}

No. 219 分葉は著明認められる。中排泄管を中心として，小排泄管及び終末装置より構成される，腺腔 の拡張は終末装置に著明に認められる。内腔に分泌物を証明する。間質脂肪組織可良。

\section{\& P 後15日}

No. 478 分葉はあまり著明でない，終末装置の数は多く，練胞の発育はよい，排泄管は閉鎖状であるが， 内腔に分泌物を証明する，閻質部の発育岕よいが，あまり充血岕見られない，又毛細血管の数も少い。

\section{\& $\mathrm{P}$ 後16日}

No. 220 間質部，特に脂肪組織の発育可良，中排泄管周囲に小排泄管が集合して認妨られる.内腔に分泌 物は証明出来ない.

No.464 分葉は著明に認められるが，乙れを構成する排泄管及び終末装置の上皮細胞の発育が不良である. 内腔も閉鎖している，又，内容も認められない，間質部の発育可良，充血し，脂肪組織の発育は著明である， 
(附図 8 参照)

\section{$\S P$ 後17日以降}

符 5 表に示す 3 例は，P実験をしたまま妊娠側が分娩し，Pをこのまま持続した例である，P実験の状態 では授乳は因難であつて，乙の例は分娩後 8 日迄授乳を続けた例である.

No.303（P期䦙17日）中排泄管周团に小排浛管が多数に認められる。腺小葉形成は認められない，終末

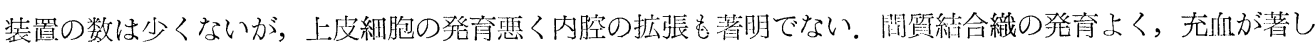
i.

No. 305 (P期聞19日）腺小葉は認められないが，小排泄管周囲に終末装置を認め，No. 303 と所見に大差 はないが，終末装置の発育は，乙の乳腺の方が可良である。

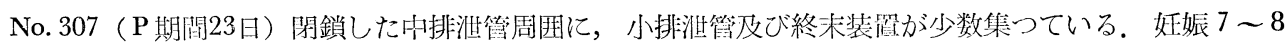
日の組織像に似ているが，小排泄管の拡張可良で，内容を認める。

\section{3. 実験例の総括}

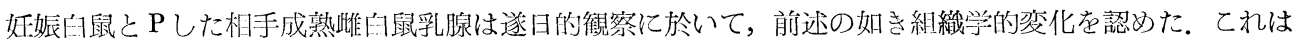
妊娠白鼠よりの移行した Hormon による作用と考光られる。即ち，弤娠白鼠と成熟雌们鼠のPに於いては， 姃娠側より相手侧の乳腺に变化学及ぼすに足る充分な星の Hormon が移行するととが明らかとなつた。 て の哥は弤娠白鼠の体内では妊娠によつて, 各内分泌蔵器及び胎盤に於いて分泌された Hormon が, 正常成 熟時に比較してP 方法によつては過剩分泌現像が起つているのではないかと思われる．相手側成熟雌乳腺の 恋化は，前編で記載した妊娠性恋化と聊か組織学的に所見を異にした. 即ち成熟雌側に移行した Hormon

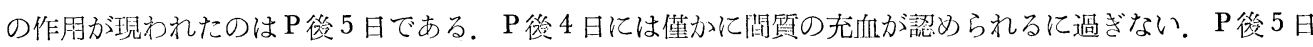
に小排泄管の增殖が著明に認められ，終末装置が僅汃出現し，その周囲の毛細血管が拡張した。

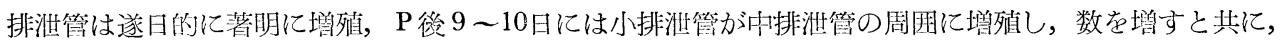
その内腔が拡張して分泌物を認める。分泌物はエオジン好染物質で脂肪顆粒を証明し，なかに上皮細胞も認 められた．腺小葉は $\mathrm{P}$ 後10日に小さな集団として認めるが，P徐14日には㿦明となつた．しかし終末装置は さほどの增殖は認められず，正常弤娠期の発育とはその組織像を異にし，小排泄管に比し，終末装置の数が 少い，P後12日頃より個々の細胞の発育はよいが終末装置の数はさほど嬶さない. 内腔の拡張も見られた。 しかし $\mathrm{P}$ 後16日以後分葉は不明瞭となり，終末装置は萎縮して，発育も悪く，内腔は閉鎖状である。

間質部は $\mathrm{P}$ 欲 4 日で先ず允向が認められ，6 日目以後は脂肪組織が著明に增殖した， $\mathrm{P}$ 後10日以後の分葉 が著明に見られる時期は，発育よく，腺小葉周囲の毛細血管の拡張が著朋である。而して，P後16日以後腺 小葉か涹縮するにつれて閆質部は更に増殖する傾向が見られた。

\section{第4章 柏手白鼠を去勢雌にした実驗}

\section{1. $P$ 実験成績}

妊娠白鼠と去勢䧳との $\mathrm{P}$ 組合せは15例行つた（前章の成熟例に比べて麻醉死等の術後 2 日以内の死亡は 多く，この例は省いた.）

$\mathrm{P}$ 実験中の死亡は成熟例に比べて多く，乙れも去勢側の死亡である。

弤娠側白鼠の妊娠期間の变動は見られない.

術後に弤娠側白鼠の臸口に，血性粘液或いは凝血を証明したのは成熟例と同じで，術後 2 ○日間認めら れた。

2. $P$ 後の遂日的観察による乳腺所見（符 6 表）

\section{\& $\mathrm{P}$ 後 4 日}

No. 465 大・中排泄管は閉鎖状，小排泄管は稍々拡張している．終末装置の数は少いが存在する．間質部 の発育は不良である。

No. 469 中排泄周囲に，小排泄管並びに終末装置が散在している．間䓄は軽度の充血が認められる， 
第 6 表 $P$ 実験去勢雌乳腺所見

\begin{tabular}{|c|c|c|c|c|c|c|c|c|c|c|c|c|c|c|c|c|c|c|c|c|c|c|}
\hline \multirow{3}{*}{$\begin{array}{l}\text { 番 } \\
\text { 号 }\end{array}$} & \multirow{3}{*}{$\begin{array}{l}\text { 時 } \\
\text { 期 }\end{array}$} & \multirow{3}{*}{$\begin{array}{l}\text { 腺 } \\
\text { 小 } \\
\text { 葉 }\end{array}$} & \multirow{3}{*}{$\begin{array}{l}\text { 終 } \\
\text { 胞 } \\
\text { 腔 }\end{array}$} & \multicolumn{3}{|c|}{ 大排泄管 } & \multicolumn{3}{|c|}{ 中排泄管 } & \multicolumn{3}{|c|}{ 小排泄管 } & \multicolumn{4}{|c|}{ 終末装置 } & \multicolumn{3}{|c|}{ 間 } & \multicolumn{3}{|c|}{ 質 } \\
\hline & & & & \multirow[b]{2}{*}{ 数 } & \multicolumn{2}{|c|}{ 内腔 } & \multirow[b]{2}{*}{ 数 } & \multicolumn{2}{|c|}{ 内腔 } & \multirow[b]{2}{*}{ 数 } & \multicolumn{2}{|c|}{ 内腔 } & \multirow[b]{2}{*}{ 数 } & \multirow{2}{*}{$\begin{array}{c}\text { 細 } \\
\text { 胞 } \\
\text { 発 } \\
\text { 育 }\end{array}$} & \multicolumn{2}{|c|}{ 内腔 } & \multirow{2}{*}{$\begin{array}{c}\text { 発 } \\
\text { 弆 }\end{array}$} & \multicolumn{2}{|c|}{ 血管 } & \multicolumn{2}{|c|}{ 毛細管 } & \multirow{2}{*}{\begin{tabular}{|l} 
皮 \\
下 \\
脂 \\
肪
\end{tabular}} \\
\hline & & & & & $\begin{array}{l}\text { 拡 } \\
\text { 張 } \\
\text { 度 }\end{array}$ & $\begin{array}{l}\text { 分 } \\
\text { 泌 } \\
\text { 物 }\end{array}$ & & $\begin{array}{l}\text { 拡 } \\
\text { 張 } \\
\text { 度 }\end{array}$ & $\begin{array}{l}\text { 分 } \\
\text { 泌 } \\
\text { 物 }\end{array}$ & & $\begin{array}{l}\text { 拡 } \\
\text { 張 } \\
\text { 度 }\end{array}$ & $\begin{array}{l}\text { 分 } \\
\text { 泌 } \\
\text { 物 }\end{array}$ & & & $\begin{array}{l}\text { 搪 } \\
\text { 張 } \\
\text { 度 }\end{array}$ & $\begin{array}{l}\text { 分 } \\
\text { 泌 } \\
\text { 物 }\end{array}$ & & 数 & $\begin{array}{l}\text { 拡 } \\
\text { 張 } \\
\text { 度 }\end{array}$ & 数 & $\begin{array}{l}\text { 拡 } \\
\text { 張 } \\
\text { 度 }\end{array}$ & \\
\hline 465 & $\mathrm{P}$ 後 $4 \mathrm{~T}$ & - & - & + & \pm & - & + & \pm & - & + & \pm & - & + & \pm & \pm & - & + & + & \pm & + & + & \pm \\
\hline 469 & $\mathrm{P}$ 後 $" 1$ & - & - & + & \pm & - & + & \pm & - & + & + & - & $H$ & + & + & - & + & + & $H$ & + & + & + \\
\hline 309 & $\mathrm{P}$ 後 $5 \mathrm{~T}$ & - & - & + & + & - & $H$ & \pm & - & $H$ & + & + & + & + & + & + & + & + & + & + & + & + \\
\hline 240 & $\mathrm{P}$ 後 $7 \mathrm{~T}$ & - & - & + & \pm & - & + & \pm & - & H & \pm & + & $H$ & \pm & \pm & \pm & + & + & + & + & + & + \\
\hline 300 & $\mathrm{P}$ 後 11 & - & - & + & + & - & + & + & - & + & + & - & \pm & \pm & \pm & - & + & + & \pm & + & \pm & \pm \\
\hline 470 & $\mathrm{P}$ 後 $8 \mathrm{~T}$ & - & - & + & \pm & - & + & \pm & - & + & $H$ & - & $H$ & + & H & - & + & + & H & + & + & H \\
\hline 467 & $\mathrm{P}$ 後 $" 1$ & - & - & + & + & - & + & + & - & + & + & - & + & \pm & \pm & - & + & + & + & + & + & H \\
\hline 466 & $\mathrm{P}$ 後 $9 \mathrm{~T}$ & - & - & + & + & - & + & + & - & + & \pm & + & + & + & H & + & + & + & + & + & + & + \\
\hline 310 & $\mathrm{P}$ 後 $10 \mathrm{~T}$ & - & - & + & + & - & $H$ & $H$ & + & $H$ & it & + & + & + & + & + & + & + & $H$ & + & $H$ & H \\
\hline 468 & $\mathrm{P}$ 後 $11 \mathrm{~T}$ & - & - & + & \pm & - & + & \pm & - & t & + & - & + & \pm & + & - & + & + & + & + & + & + \\
\hline 312 & $\mathrm{P}$ 後12 T & - & - & + & + & + & $H$ & $H$ & + & $H$ & H & + & \pm & \pm & \pm & + & + & + & $H$ & $H$ & $H$ & + \\
\hline 314 & $\mathrm{P}$ 後14T & - & - & + & H & $+t$ & $H$ & $H$ & $H$ & HI & H & +1 & \pm & \pm & \pm & + & + & + & $H$ & + & + & \pm \\
\hline 316 & $\mathrm{P}$ 後 $15 \mathrm{~T}$ & - & - & + & HH & $H$ & H & HI & $H$ & + & \pm & + & + & \pm & \pm & +1 & $H$ & + & +1 & + & $H$ & + \\
\hline
\end{tabular}

\section{$\S P$ 後 5 日}

No. 309 排泄管，特に小排泄管が多数に認められ，稍々拡張する，終末装犆は数は少いが発育はよい。閐 質部には脂肪組織が著明に発育している。

\section{§ $\mathrm{P}$ 後 7 日}

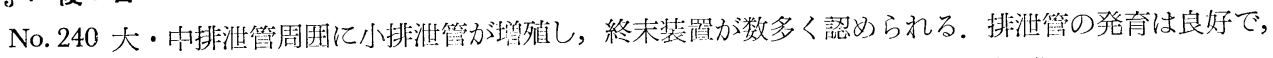
拡張は著明でないが少量の分泌物を認める。閣質部には特に所見がない（附図 9 参照)

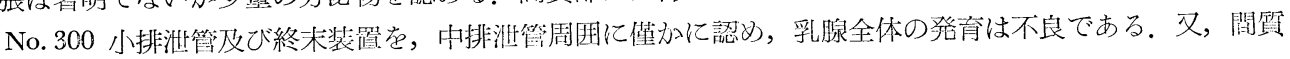
部の発育も不良で, 脂肪組織も少く, 血管の拡張もない.

\section{$\S P$ 後 8 日}

No. 470 間質脂肪組織の発育よく，その中に排泄管及び終未装䁂を認める. 大・中排泄管は閉鎖状である

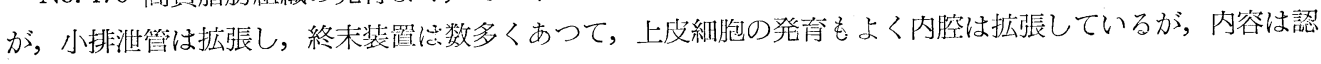
められない. 間質部は充向し，毛細血営の拡張が著明である。

No. 467 前例No. 470 と略々同様の所見であるが，小排泄管及び終未装置の発育は稍々不良である。

\section{\& $\mathrm{P}$ 後 9 日}

No. 466 中排泄管を中心として小排泄管があり，その周りに終末装置が 8～10個集つて存在する. 終末装 置の数は少いが，上皮細胞の発育よく，核も大きい.内腔は広く拡張し，分泌物を認める. 小排泄管も龶腔 の拡張はさほど著明でないが，分泌物を少量証明する。（附図10参照）

\section{§ $\mathrm{P}$ 後10日}

No. 310 中並びに小排泄管が多数存在し，発育よく，内腔が高度し，分泌物を多悬に認める. 分泌物は工 オジン好染物質で脂肪顆粒を証明する。しふしてれに比較し終末装置の数は少い. 内腔に分泌物を証明する。 間質部の允血は著明に認められ，毛細血管の拡張晋しい，脂肪組織の発育もよい（附図11参照）

\section{$\S P$ 後11日}

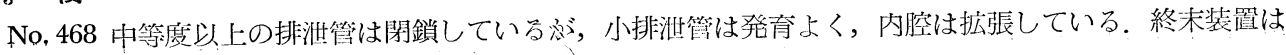


数多く認吼るが，上皮細胞の発育不良で内腔は閉鎖している，間質結合織の発育はよいが，血管系の拡 張はさほどない。

\section{$\S P$ 後12日}

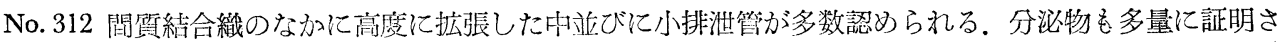
れる。乙れに反して終末装犆が少く，ての発育も不良で内腔も閉鎖している。排泄管周囲は結合織の增殖が 著明で，脂肪組織が少い，毛細血管は拡張し間質全体が充血している。(附図12参照)

\section{$\S \mathrm{P}$ 後14, 15日}

No. 314 及び No. 316 前述したNo. 312 と同一去勢白鼠乳腺で，妊娠側が分娩した後も離解せずにP した例である。妊娠側はNo. 314 が分婏後 3 日，No. 316 が分婏後 4 日である.

No. 312 亿比較して排泄管は更に拡張し，終末装置は少く，No. 316では高度に拡張した排泄管を多数認 めるが，小排泄管の数は少い，内腔に多量の分泌物を証明し，排泄管上皮は 2 首の扁平上皮で，核は濃染し 紡鍾形を呈している。排泄管周囲の結合織は增殖しているが，間質部の脂肪組織は少い。

\section{3. 実験例の総括}

姃娠白鼠と Pした相手去勢雌白鼠乳腺は，遂日的観察に於いて，前日の如き組織学的変化を認めた，即ち， 前章の成熟睢白鼠を相手とした $\mathrm{P}$ 実験と同様に，弤娠側より去勢白鼠の乳腚に解剖的にを組織学的にも変化 を及に゙す有効なる Hormon の移行が明ら加に認められた。而して，乙の乳腺の变化は娃娠性変化と多少異 つた堌殖であり又分泌像であつた。

去勢側に移行した Hormon の作用発現が明確に認妨れたのはP後7 日である。P後4〜 5 日では間質 部の立血，小排泄管の堌殖が僅かかに認められた。P後7 日では排泄管の增殖が著明に認められ，内腔も稍々 桩張し，分泌物を少量であるが証明出来た。 $\mathrm{P}$ 後10日に於いては排泄管内腔の拡張が著明に観察出来，P 後 12日では更に拡張は高度となり，小排泄管の数は減じた。

終末装置は遂日的に数を増したが，P後 9 日で小排泄管周囲に 8〜10個，P 後11日では僅かに数を增した 程度である，排泄管の增殖に比して，終末装置の数が少いととは前章の些験例と同じであつた。

間質部は $\mathrm{P}$ 捘 4 〜 5 日で先ず允血を認め， $\mathrm{P}$ 後 8 〜 日には脂肪組織の增殖が著明であるが， $\mathrm{P}$ 後12〜13 日では，量的に少くなる感があつて，排泄管周囲には增殖が著明に認められた。

本实験例と成熟雌 $\mathrm{P}$ 実験例と比較して観察すると, 乳腚の堌殖並びに分泌像を呈することは同じ椂な経過 であるが，成熟例と比べてその発現が時間的ずれがあつて 3 4 日遅れて起る樣に考えられた，又，本実験 乳腺では腺小葉の形成は全例に殆んど認められず，終末装置が前章の例より更に少く思われた。

\section{全編にわたる䫖括並びに考按}

1. 白鼠乳腺が Green $\mathrm{e}^{13)}$ の記載する様に通常胸腹部に左右 6 対を数えている. 而して, 弤娠, 産䁦期の 乳腺の発育著しい時は一部肋骨縁下で中断するが胸腹部に広く発育拡張している。

私の实験に於いて，一定期間実験動物を遂日的観察する事により，各乳腺間の組織学的差異の有無を明ら 加すする必要を感した。各生理時期に於いて 1 匹の白鼠の全乳腺を切除し, 各乳腺を比較検索した所, 産浱 期を除いて他の時期に所見の差異を認められなかつた。即ち，産裖期に於いては乳頭の損傷等により授乳の 行われなかつた乳腺は，その動物の他の乳腺に授乳が行われていても乳腺の所見を異にするものである．泌 乳には授乳剌戟が必要な条件であるととは既に周知のことであるが，乙の事笑を更に同一の動物の乳腺に於 いても証明するてとができた。即ち，乳腺発育並びに泌乳現象が体液により，支配調節されても，授乳の行 われない一部の乳腺は, 組織学的に異つた所見を呈した。

2.1922年 Rosenberg ${ }^{29}$ ) は乳腺に於ける週期的変化は，子宮内膜と同じで月経過期の黄体期に一致して

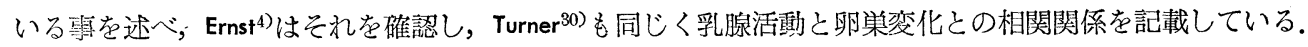
藤森 ${ }^{6}$ そよれば人乳腺は月経週期に従つて增殖と退行を繰り返し，堌殖は月経終了後 $2 \sim 3$ 日より月経前期 
迄続き，月経直前又は開始と共に退行が 7〜8 日間続く. そしてての内分泌的考察として Estrogen 及び

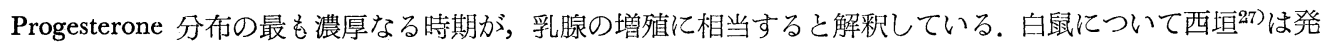
情期に於いて稍々血管多く充血の感があり，他は週期に於いて大差はないと述べている。

白鼠の性週期は 4〜 5 日に反復し ${ }^{19)}$ 小山，中尾の分類によれば，間期 (57時間)，上皮期 (12時間)，上角 期 (12時間)，角化期 (24時間) と規則正して発来する。私の実験に於いて間質部の充血を角化期及びその 翌日に認めたが，乙の時期は白鼠の卵栄に於いて，卵胞成熟，排卵，黄体形成の時期 ${ }^{22}$ にあたる。いずれに せ上白鼠乳腺が著明なる変化を来さないのは，之の性週期が短時日の反復であり，又乳腺に変化を来す Hormon の有効量が分泌されないか，例え分泌されたにせよ，時閪的に短時間であるかとも考劣られる。

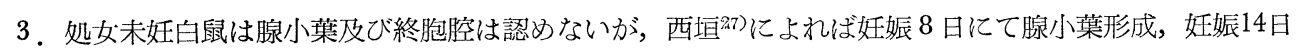
で僅かの終胞腔を認め，18日以後に終胞腔より成る真の腺小葉を認めた。不村 ${ }^{21}$ は妊娠 10 日で腺小葉を認め， 16日目に終胞腔より成る腺小葉を認め，管腔中に漿液性分泌物及び初乳球が散在すると記している.

私の実験に於いても略々同様の経過並びに所見を得たが，腺小葉及び終胞腔等の発現時期は白鼠の系統に よつて多少異るとも考えられる.腺小葉並びに終胞腔発現時期の問題は乳腺が泌乳を目的とした発育段階に 於いて最も重要な時期であるてとは言うまでもない，本実験に於いて乳腺の発育過程を列記すると次の如く である. 間質部充血, 小排泄管潧殖 $(5 \sim 6$ 日), 終末装犆增殖 $(6 \sim 7$ 日), 間質部特に脂肪組織增殖 $(7$ 日), 中排泄管管腔拡張 $(8 \sim 9$ 日), 腺小葉形成 (10 11日), 終胞腔出現 (16日), 終胞腔上皮細胞の泌乳 現象（18１9日）等，経過を打つて発育し，その後は腺葉の增殖，排泄管の拡張により授乳により授乳対 する準備を完了する。遂日的钼察に於いては表で見る如く一様でなく $2 \sim 3$ 日の相違がある. 特に後半期泌 乳現象が起きた後は同じ妊娠日数でも分泌の程㢄が異り, 又妊娠日数の浅い乳腺の方が泌乳現象が盛んな所 見が見られる. てれは白鼠の妊娠期間が一様でなく，21〜23日で $2 \sim 3$ 日の相違がある. この事より乳腺発 育を判断する際，分婏前何日の乳腺と考えた方が或いは的確な表現とも考えられる.

経妊白鼠に於いては, その妊娠性变化が早期起り, 妊娠 7 日で小葉形成, 娃娠13日で終胞腔が認められた。 その発育過程は処女乳腺と同様の経過をたどるが，その相違点は時間的なずれのあるてとである（妊娠期 間は初妊経妊の差はない） てれは $\mathrm{P}$ 実験に於いても，相手側白鼠が経妊の場合乳腺の変化が早期に現われ る事を知つた。

4. 授乳期は乳腺の最も活動的な機能を発輝する時期であり, 又雌性乳腺の本来の目的である泌乳作用が 起る時期であるととは言うに及ばず。藤井 ${ }^{8}$ はての時期の組織像として, 腺胞の網目状拡張と腺胞の分泌 状態を, 泌乳の有無の判定目標とした。 汃かる時期の Hormon 分泌状態を妊娠期に增量した Estrogen, Progesteron 等が急に正常非弤時以下に下降するてとに関連を求めている. 実際 Estrogen, Progesteron は 徐々に正常值に恢復するが，Prolaction のみは增量してくる．ての泌乳に対して決定的主役を演ずるのは Prolactin であるてとは認めざるを得ない，白鼠乳腺に関して木村 ${ }^{211}$ は分婏時に於いて，乳腺実質の発育及 び泌乳に関してのべ, 組織学的に腺小葉完成し, 終胞腔の開大並びに分泌物証明, 及び腺細胞内の脂肪顆粒 を証明している. 又, 西画 ${ }^{27}$ は産裖 1 日に於いて終胞腔が著明に拡大し, 分泌物を充し, 妊娠期の数倍の大 きさを有するてとをのべ，且つ産褥末期に於いて，乳腺が腺腔の縮小した萎縮形をとると述べている.

私の笑験江於いて産裤 2 日に，授乳の形跡を証明し，腺小葉は完全な網目状の拡張をなし，その分泌現象 として終胞内腔の乳汁証明，終胞上皮内脂肧顆粒，終胞腔上皮核の淡染，並びに細胞内腔側の細胞膜の破綻 様所見等がその特徽として挙げられる。しかし, 産裖末期になると泌乳現象の退潮として, 腺小葉の縮小, 並びに閪質結合織の堌殖が授乳のあるなしに拘る。即ち，離乳期に認められる組織所兒は産裖末期に於いて 既に起つて来るととを知つた。

5. 離乳期の乳腺は奸娠期及び産裖期の乳腺の最も活動的な時期をすざて静止状態に移行する過渡期の経 過をとる。即ち, 分泌機能を有する腺胞が消失して, 皮下絬合織中に小数の排泄管及び終末装置が認められ

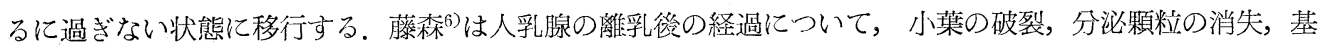
礎膜の中断及び萎縮, 経末管の縮小, 脂葉組織内外の円形細胞浸潤, 含喰現象の順序に起り, 而して後に再 
び乳管及び周囲結合織の再生と終末腺管芽の更新，增殖が行われると述べている。Berka ${ }^{22}$ は乳腺の退縮期け

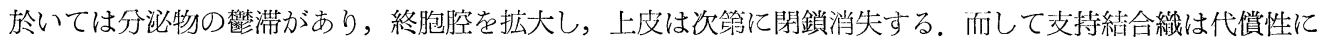

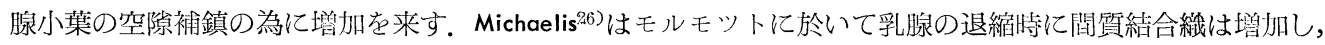
好酸球, 白血球の出現するてとを認め，退縮特に初乳が再び発露するという。

離乳期に於ける乳腺の退縮現像のうち，特に要なととは泌乳停止，終胞腔の消失である。西垣 27 は白鼠に 於いて，離乳後 5 日目に終胞腔は小数となり，8 日目には終胞腔は認妨らず腺小葉の萎縮に変つて，血管 に富む間質組織か溌育する。15日目には腺小葉か明確に認められないと述べている。藤井 は特異分泌像が消失して泌乳が止むと云う。望受 ${ }^{24}$ （家鬼実験）は授乳作椆の停止と共に，終胞腔は漸次萎

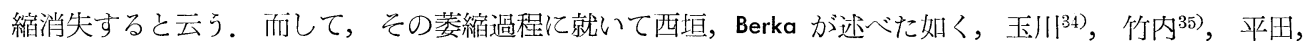

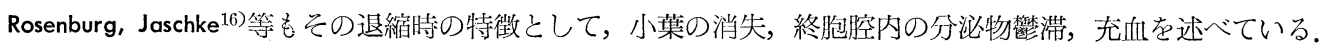
私の実駼に於いては，萎縮過程で終胞腔は滩乳翌日には急激江縮小するが，之れ以後は一㭙に一様に開鎖 せず，各小葉により異るが，5 日目には大部分が閉鎖している，7 日目以後には終胞腔は証明出来ない，間 質部の発育は離乳期に於いて最も着目する点であり，先ず血管系の增列估始まり，腺小葉の美縮に反比例し て血管系結合織がその位置を占める. 小葉内毛細管の拡張及び小葉内結合織線維の発育は $2 \sim 3$ 日目の比較 的早期に起きる。しかし間質部の発育は腺策が萎縮する迄䫓者に残つていて，10日目以後に退縮が見られる。 分婏後離乳乳腺は，授乳後離乳腺と比へでの退縮は著明でなく，分婏後 2 ～ 3 日はさほど腺腔の縮小は 見られない.しかし 4 日目より急激飞菱縮し，内腔閉鎖が始まり，8 日目以後は終胞腔は証明出来ない.

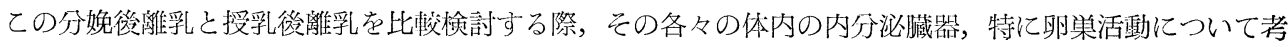
察しなければならない，竹脇33゙によれば自鼠は分婏後後早期に排卵が起き，以後授乳により，排卵は抑制さ

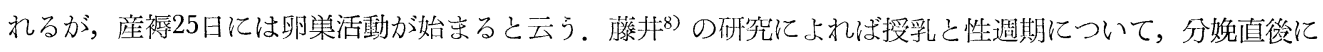
離乳すると 6 ～ 8 日目に性週期が始索り，授乳が不完全になつてから離乳すると，速かに性週期は起る。又， 自然のまま授乳を続けても20日以谽は不完全授乳になる。乙の状態では35〜39日頃から性週期が始まると云 う.

特に乳腺菱縮期に於いて，腺葉の菱縮縮小，終胞腔の閉鎖並びにその消失等の特期は脳下垂体，卵巣系の 活動が大であると考えられるが，乙れは今後の研究に俟たねばならない，又，分娩衡離乳乳腺所見中，排泄 管の開大並びにその内腔に分泌物が見られる事は内分泌腺の作用のみを以つては説明できない事で，授乳後 離乳乳腺が離乳時に既に自然と萎縮所見か現われた点など授乳による吸引の有無等も考えられる事ではある が，内分泌腺の作用と密接なる関係のあるととは想像に難くないとてろである.

6. 哺乳動物の $P$ 実験に関する研究は1860年 Paul Bert の行つた研究を始めとして，現在に至る迄多方 面にわたつて P 法は研究方面に利用されている，P方法の定義について小山 ${ }^{199} は " 2$ 匹の動物を手術により 分離出来ない様に瘾着して，血行等を互に通じさせ，肉体関係を一緒に共存させたものの事である。と述へ

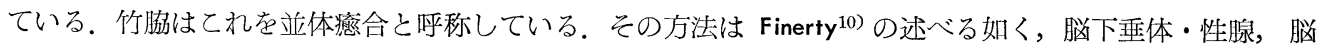
下垂体・甲状腺，脳下垂体・副肾等の関係，脳下垂体の生長 Hormon の研究，副腎に対する性の影響，乳 腺の研究，糖疗病，婜と高血王，皮虞移植，神経吻合，腫煌移植等の多方面にわたつて行われている生物学 的研究法の一つである。また内分泌臟器の相関関係を梌索する上に於いてもP 法は最も興味ある方法であつ て，最近では脳下垂体・性腺系の研究が最を進んでいる。

$\mathrm{P}$ 実験は相互動物の皮膚, 筋肉, 腹膜を側腹部に於いて縫合するととにより，相互間に体液の交流が起る ことを目的としたものであつて, 体液の交流は一般に確認された牙実である。これと同時に相互閆に Hormon が移行する事が，相互動物の各種の組合せに於いて証明されている。

しかし Christensen ${ }^{3)}$ の実験の如く，成熟雌同志の $\mathrm{P}$ 害験に於いて，相互間の性週期に影響なく，夫々の雌 は独自の性週期を繰り返していると云う。灭，成熟雌雄の組合せ亿於いても，雙側の性週期に変化を見ず，

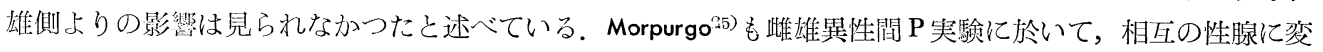
化を証明しなかつたと述べている，谷津 ${ }^{36)}$ もての方法を追陚してその事実を確認している，てれらは正常成 
熟動物のP 実験に於いて，相手側の各臓器に変化を起す Hormon が移行しないか，Hormon 量が同じであ れば相怙抗するか，或いは变化を起すに足る有效量が移行しないものとも解勫される。即ち，正常生理状態 にある動物は常に Hormon 分泌が均等であつて，P 方法によつて見てきその体内で過剩の Hormon 分泌を

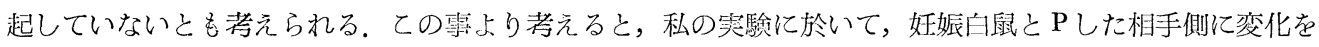
起した事は，妊娠白鼠がP方法によつて見てもその体内で過剩の Hormon 分泌を行つていることを確認す るととができる。

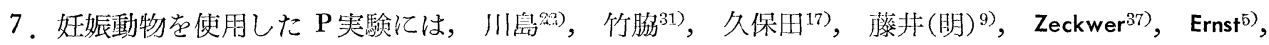
Pfeiffer u. Zachel ${ }^{23)}$ 等の報告が見られる。 そのP 実験に使用した娃娠動物の妅娠期間について, Ernst は妊

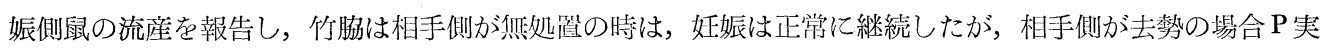
験が奸娠14日以前に行われると姃娠継続は出来ないと述べている。私の実験に於いては，娃娠期間について その相手が成熟䧳或いは去勢雌であつても，さほどの妊娠期淮の変化が見られなかつた。

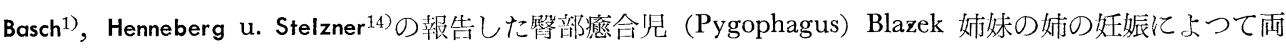
者に起つた変化についての症例報告は，P実験者及び乳腺の研究者にとつて與味ある発表であつた。乙の姉

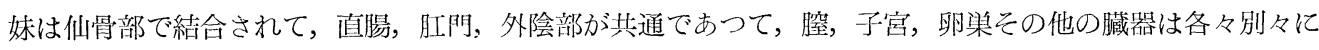
あつたが，月経は常に同侍に起きたという。一方の姉が妊娠して㠫月経が起きたが，妹は分婏前 8 週迄月経 があつた，乳腺については，姉の分娩後 8 日目に妹に泌乳現象が起つた。乳房の発育は非娃の妹の方が良好 で，泌乳も産婦の姉より良好であり，Basch は妹の方が以前より栄䬭状態よく，又皮下脂肪に富んでいたて とによると記載している。而して Basch はこの㱏例より泌乳が体液性機棰により調節される事を主張した。

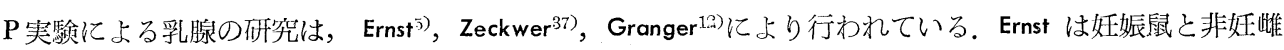
鼠とのP 実験に於いて, 非妊側処女鼠に妊娠性変化が起きたてとより, 乳腺発育の体液的調節を確認した。

Zeckwer は去勢鼠一成熟雌に於いて, 去勢側加らの Gonadotropin 移行により, 成熟雌側畉柴に過剩の Hormon 分泌が起き，その事より乳腺に変化を認めたと記している，又，Granger は去勢下垂体剔出雄又は 雌白鼠に Estrogen (Estradiol dipropionate 10r×10) を投与して，その相手白鼠に成熟雌，去勢堆，去勢雄 を選び $\mathrm{P}$ 実験を行つたが，実験対称の単独去勢脳下垂体剔出白鼠乳腺に変化を認めなかつたのに，脳下垂体 を有した白鼠とのP 実験を行う事により乳腺に変化を来した。そのうちで成熟雌をP の相手とした組合せに 於いて特に著しい乳腺の変化を証明した。 ての事より白鼠乳腺発育に於いて Estrogen と共に脳下垂体の存 在を重要視している.

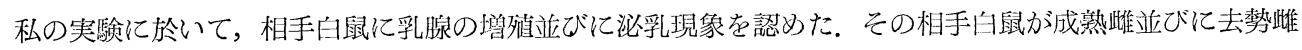
共に同じく所見を認めた，双方の比較には特別の差異なく，発育が特間的に遅速を認めたに過ぎない，即ち， 成熟雌の方が去勢側より変化が早く起きたが，その発育する過程には組織学的に差異を認めなかつた。この 実駼に因つて相手白鼠の卵巣の有涠には特別の意義を見出し得なかつた。

3. Ernst の実験では成熟処女雌に乳腺の增殖及び泌乳を証明したが，私の実験に於いても娃娠白 鼠と $\mathrm{P}$

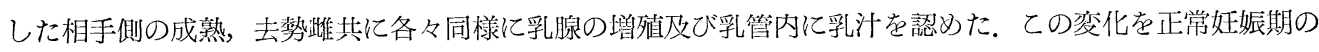
乳腺変化と比較すると，一定期間は略々同様の経過をとつたが，その後は卵加所見を異にした．即ち，排泄 管特に小排泄管，終末装䈯の発育が炲り，腺小葉形成に至る妊娠10〜11日頃迄の発育経過は㱠んど同様であ るが，それ以後腺小葉增殖，終胞腔形成の畤期となつてもそれを見るに至らない．しかるに排泄管の発育が 著しく，内腔が高度に拡張し，内に分泌物を証明するに至る所見は大いに異るとてろである，而して妊娠期 の如く排泄管增殖につれて，終末装置が增殖するてとがない，本実験に於いても終末装疽の発育が極めて悪

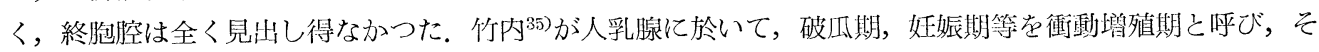
の急速の変化老腺增殖，間質の立血，及び乳管外首細胞の水腫状肥大によるものであるとした．本実験に於 いてを乳腺所見は，成熟雌はP 後 5 日，去勢雌では $\mathrm{P}$ 柊 7 日より急速の変化を認め，一定期間，竹内の述へ る如き経過をとつた。

9、白鼠乳脉の热育並びに泌乳に関する内分泌学的考察として Geschickter ${ }^{11)}$ は, 乳腺の正常な発育をもた 
らす Hormon は，Progesteron 1 単位に対して Estrogen $5 r$ が適正比と述べている．藤井多は各 Hormon

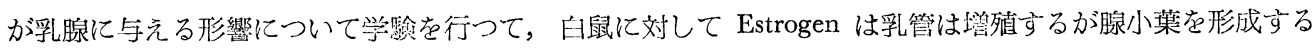
傾向が少く，乳管は拡張して脂肪染色陽性の分泌物像を示すと云う。而して Progesterone 単独では殆んど， その作用は認められず，Estrogen と Progesteron の併用投与に於いて乳管腺胞系の增殖があり，妊娠期に 似た腺葉形成，初乳分泌像を認めたと云う。私の実駼に於いて見られた排泄管の異常增殖，並びに異常分泌 像は，藤井の述べた Estrogen 単独投与による実験的研究による異常分泌像とその所見を同じうするとてろ である. 即ち姃娠白鼠より特に Estrogen が移行して相手側白鼠に作用した様にも考えられるが，しかし妊

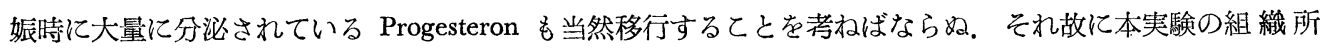
見のみを以つてその作用 Hormon を推定するてとは困難である。，又，妊娠側よりの Gonadotropin が相手 側の卵巣を刺战して，乙れによつて分泌される Hormonも考虑しなければならないが，去勢堆乳腺にも， 成熟雌と同様の組織所見を呈したととより，相手側の乳腺の変化は妊娠側より移行した Hormon の作用と 考えるのが妥当と思われる。．

\section{結語}

1. 妊娠白鼠と非妊白鼠のP P 実験を行い，非妊側白鼠乳腺を遂日的に組織学的検索を行い，次の如き結果 を得た。

1）妊娠側の Hormon が相手側の，成熟雌並びに去勢䧳に移行して乳腺に変化を及に゙す專を認めた。

2）妊娠は P 実験に於いて，その体内で過剩の Hormon が分泌されるものと思われる.

3）相手側乳腺の組織学的変化は正常弤娠時の発育と異なつた，堌殖及び分泌像が認められる．而して正 常妊娠時の泌乳に特有の終胞腔を認め得なかつた。

4) 相手側白鼠は成熟雌，去勢雌共にその乳腺の発育過程は組織学的に差異を認めない.

2. 尚, 白鼠乳腺の基礎的研究として各生理期の乳腺の態度を, 遂日的に組織学的梌索を行つた。

1）一白鼠にある各乳脉間には組織学的な差異はない.

2）性週期に於ける乳腺の変化は間質部の充血の他特別の所見を誌めない.

3）弤娠期に於いて，乳腺は一定の発育過程を経て，弤娠18日以後に泌乳染備を完了する．経産白鼠は処 女白鼠に比べて, 乳腺の発育段階が早く起る。

4) 産裖期に於いて産裖 2 日で既に高度の泌乳現象か現われ，産裖20日頃になると捊乳が続けられても， 組織像に退潮が認められる。

5）離乳期に於いて離乳 5 日目に泌乳現象が止み，15日頃には静止状態に復故する。尚分浼柊授乳を行わ ずに離乳した場合は授乳後離乳の場合と比較すると排浛管に長期に旦つて乳汁を証明した。

擱筆にあたり，恩師三谷茂教授の御指導並びに御校閲に深謝す。本論交要旨は第 8 回日本産科婦人科学会 総会に於て発表した。

\section{参 考 文 献}

1) Basch, K. : Deutsche med. Wochenschr. 36, 987 (1910).

2) Berka : Frank. Zeits. f. Path Bd. 8.

3) Christensen, M. : Acta Path. et Microbiol. Scand. suppl XXII (1953). 4) Ernst, M. : Frank. Zeitschr. Path. 31, 500 (1925)。 5) Ernst, M. : Deutsche Zeitschr, f. Chir. 202, 231 (1927). 6) 藤森：

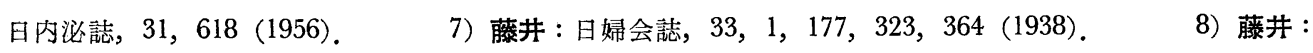
日産㷌誌，9，927 (1957)。 9) 藤井(明)：日婦会誌，27，2 (1932). 10) Finerty, J. : Physiol. Rev. 32, 277 (1952). 11) Geschickter, C.F. : Deseases of the Breast Lippincott (1945).

Granger, B.S. : Proc. Soc. exper. Biol. \& Med. 58, 320 (1945).

Rat (1955).
14) Hegnaver, H. : Zbl. Gynäk. 75, 22 (1953).
13) Greene : The Anatomy of the 15) Henberg u. Stelzner : Berl. 
永田論文附図（1）

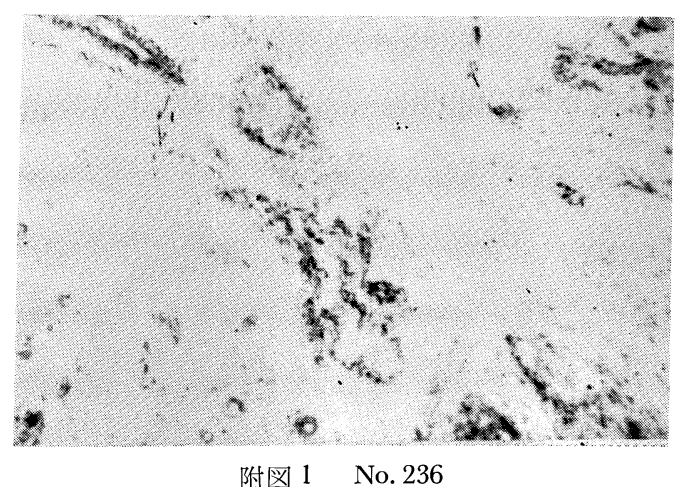

妊娠13日。下顎部に発見した乳腺

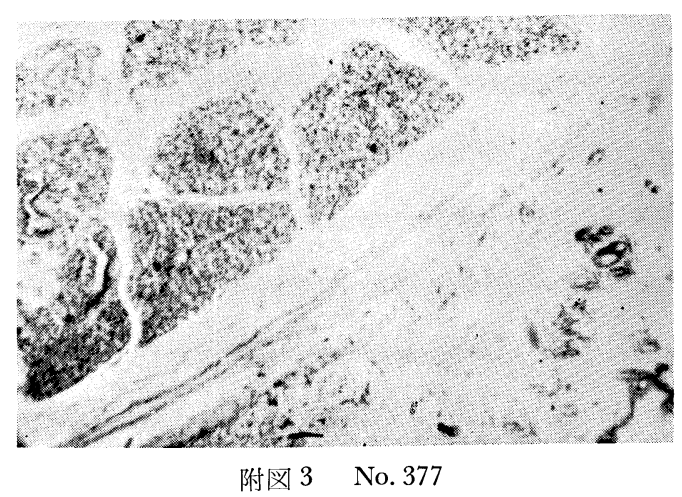

妊娠21日乳腺。終胞腔があまり拡張していない

(附図 4 と比較)

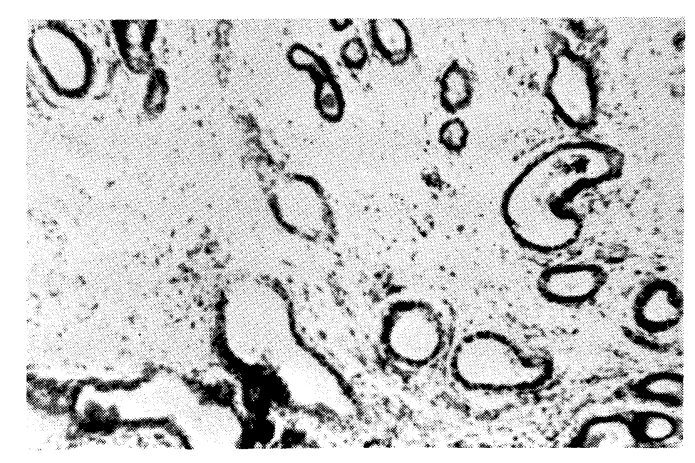

附図 5 No.459

$\mathrm{P}$ 後 9 日目成熟雌乳腺. 小排泄管の増殖著明, 内 腔に分必物を認める。

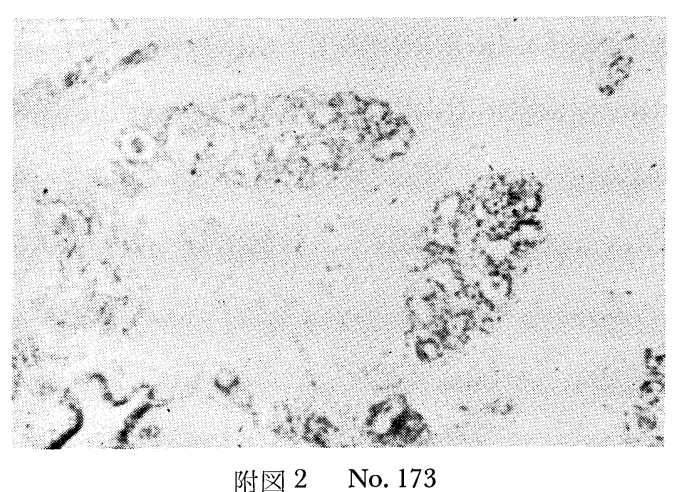

産袸 3 日。乳頭咸爛により授乳されない乳腺

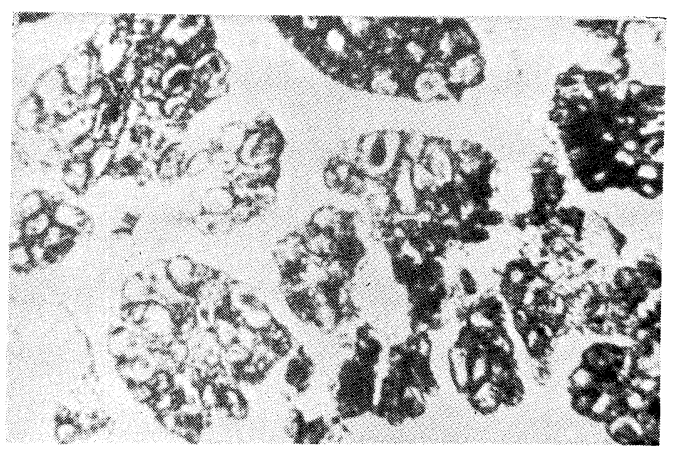

附図 4 No. 394

妊娠 21 日乳腺。終胞腔の拡張が著明, 内腔に乳汁 を証明す。

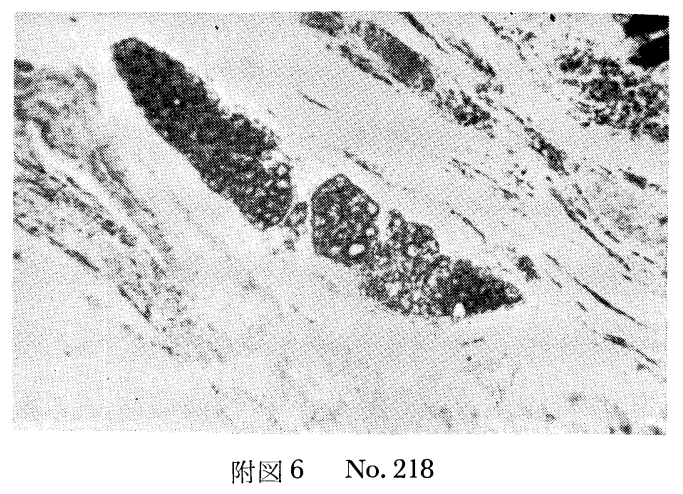

$\mathrm{P}$ 後10日目成熟雌乳腺. 分葉著明, 小排泄管及び 終未装置内腔拡張。 


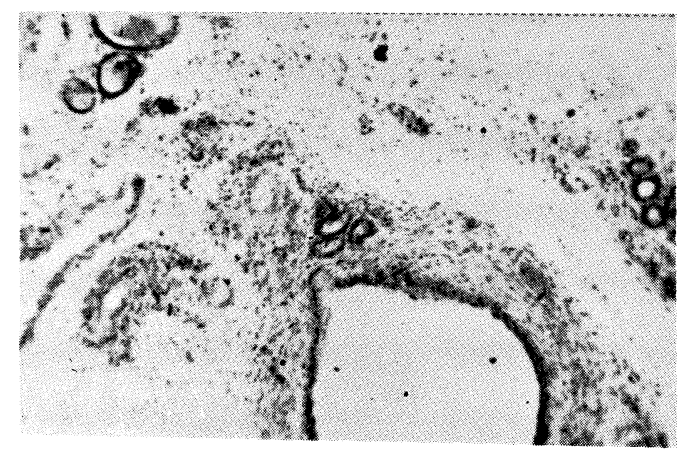

附図 7 No. 463

$\mathrm{P}$ 後13日目成熟雌乳腺. 中小排泄管腔拡張し, 分 泌物証明す。

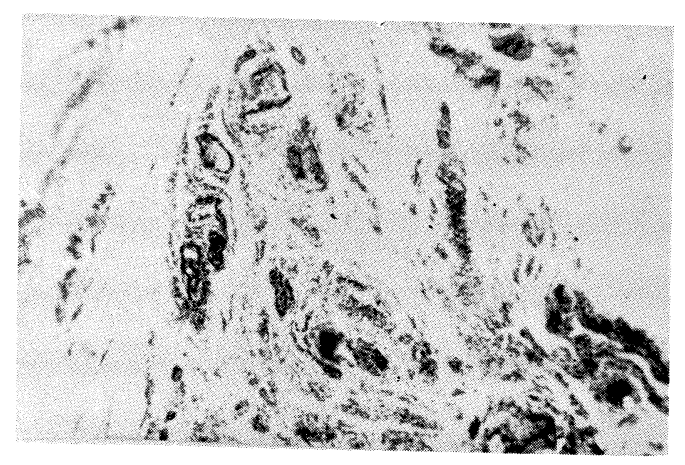

附図 9 No. 234

$\mathrm{P}$ 後 7 日目去勢雌乳腺。排泄管の增殖を認めるが 内腔閉鎖状.

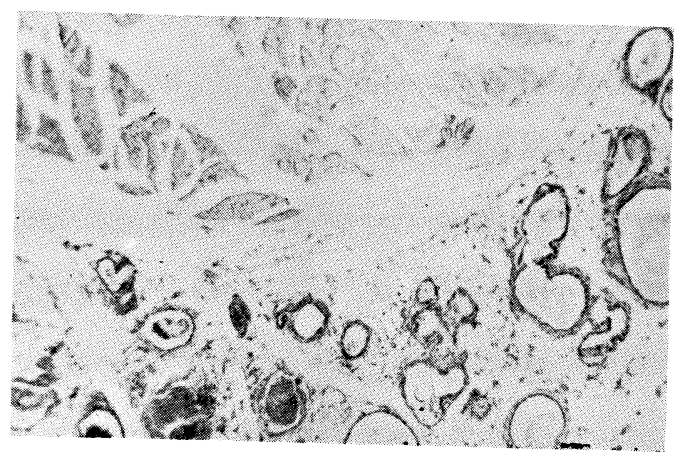

$$
\text { 附図 } 11 \text { No. } 310
$$

$\mathrm{P}$ 後 10 日目去勢雌乳腺。排泄管の高度拡張及び異 常分泌像,

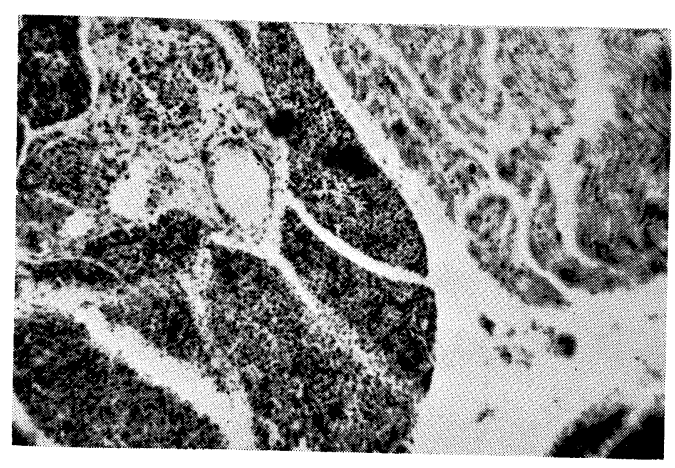

附図 8 No. 464

$\mathrm{P}$ 後16日目成熟雌乳腺。分葉著明終未装置の発育 不良.

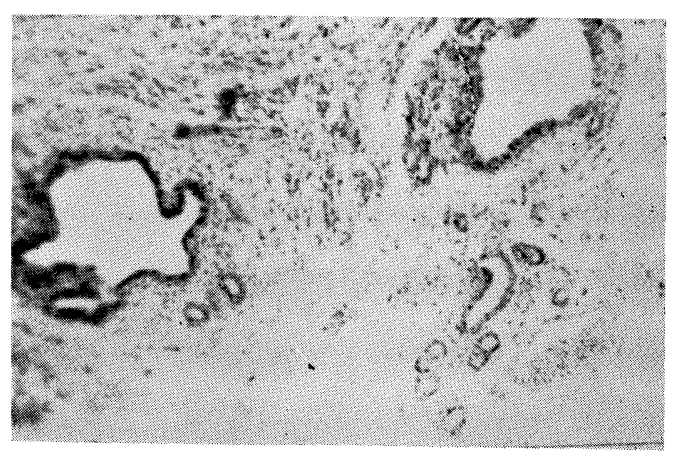

附図10 No. 466

$\mathrm{P}$ 後 9 日目去勢雌乳腺. 中排泄管周囲に小排泄管 及び終未装置増殖。

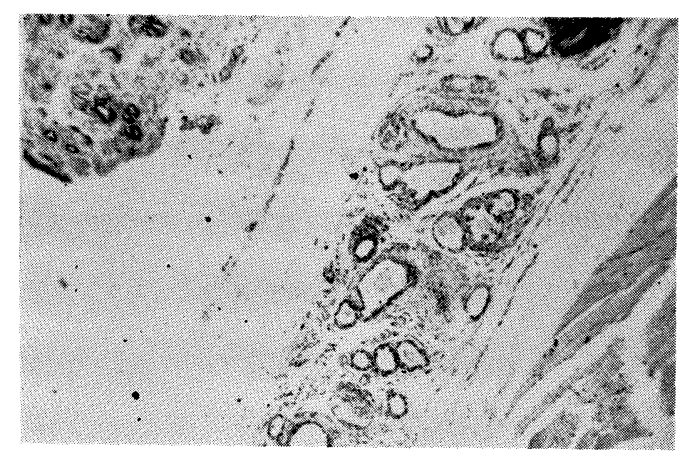

附図 12 No. 312

$\mathrm{P}$ 後12日目土勢雌乳腺。排泄管の異常分䎵像及び 排泄管周囲の結合織増殖。 
klin. Wochenschr. 40, 798, 829 (1903).

16) Jachke : Halben $u$, Seiz Bd V.

17）久保田他：日 産婦誌，6，30 (1954). 18) 久保田：日医大誌，22，685 (1954).

19）小山：動物実験手抜, 協同医書 (1955). 20) 小山, 中尾: 生体の化学, 6, 88 (1954).

21) 木村：名古屋医会誌， 51, 73, 111 (1940). 22) 川島 : J. Fac. Sci. Imp. Univ. Tokyo (Sec2) 2, 141 (1944). 三谷他 : 日産婦誌, 8, 19 (1956).

24）賏受 : 産婦紀要，22，1365 (1939).

25) Morpurgo, B. : Münsch. med. Wochens. 55, 2447 (1908). 26) Michaelis: Arch. f. Mikr. Anat 51. 西垣 : 日産婦誌, 4, 241 (1952). 28) Pfeiffer u Zachen : K.W. Nr 33 (1926).

29) Rosenburg, A. : Centralb. f. Gyn. 1912Nr $12: 1912$ Nr3. $\quad 30)$ Turner, C. Donnell : General Endocrinology (1955). 31) 竹脇: J. Fac. Sci. Imp. Univ. Tokyo (Sec4) 2, 319 (1931). 32) 竹助: 性とホルモン, 日本 評論社 (1949). 33) 竹脇 : 性現象とホルモン学 (1947). 34) 玉川 : 近畿婦会誌, 8, 677. 35) 竹內 : 東京医会誌, 30, 669 723 813. 36) 谷津 : Anat. Rec. 21, 217 (1921). 37) Zeckwer : Arch. Path. 38, 99 (1944). 